\title{
Oxidative stress and DNA damage status in couples undergoing in vitro fertilization treatment
}

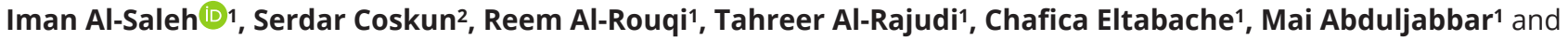 \\ Saad Al-Hassan ${ }^{3}$
}

${ }^{1}$ Environmental Health Program, Research Centre, King Faisal Specialist Hospital and Research Centre, Riyadh, Saudi Arabia 2Department of Pathology and Laboratory Medicine, King Faisal Specialist Hospital and Research Centre, Riyadh, Saudi Arabia ${ }^{3}$ Reproductive Medicine Unit, Department of Obstetrics and Gynecology, King Faisal Specialist Hospital and Research Centre, Riyadh, Saudi Arabia

Correspondence should be addressed to I Al-Saleh: iman@kfshrc.edu.sa

\begin{abstract}
This study examined the status of oxidative stress in 599 couples undertaking in vitro fertilization (IVF) treatment and its association with reproductive hormones, smoking, and outcomes. Oxidative stress biomarkers such as malondialdehyde, 8-hydroxy-2-deoxyguanosine, hydrogen peroxide $\left(\mathrm{H}_{2} \mathrm{O}_{2}\right)$, catalase (CAT), and total antioxidant capacity (TAC) were determined in follicular fluid and seminal plasma. Tail moment (TM) was used to evaluate DNA damage in the sperm and granulosa cells. Reproductive hormones in serum and cotinine (COT) in urine, follicular fluid, and seminal plasma samples were determined. Separate multivariate linear regression was used to assess associations between levels of each oxidative stress biomarker and each hormone and smoking parameter (modeled as natural log-transformed). The findings indicate that some oxidative stress and DNA damage biomarkers played a role in disrupting certain reproductive hormones in women and their male partners either by overproducing reactive oxygen species or reducing antioxidant defense capacity. Although women were nonsmokers, COT levels > 50 and $10 \mu \mathrm{g} / \mathrm{L}$ in urine and follicular were observed in 5.7 and $1.7 \%$, respectively. Levels of follicular fluid COT were positively associated with $\mathrm{H}_{2} \mathrm{O}_{2}$ and TM. We used log-binomial multivariate regression to estimate relative risks for the association between oxidative stress/DNA damage and IVF binary outcomes (fertilization rate $>50 \%$, biochemical pregnancy, clinical pregnancy, and live birth). An increase in the CAT levels of follicular fluid was associated with a 48 and $41 \%$ decrease in the risk of poor fertilization rate ( $\leq 50 \%)$ and unsuccessful live birth, respectively. After the models were adjusted for hormonal factors, the associations remained the same, except that the elevated TAC in follicular fluid became significantly associated with a decrease of $42 \%$ in the risk of poor fertilization rate $(\leq 50 \%)$. The higher antioxidant activity (CAT and TAC) in follicular fluid might positively impact specific IVF outcomes.
\end{abstract}

\section{Lay summary}

Oxidative stress occurs when antioxidant molecules are insufficient in the body to destroy free radicals that can damage the cells, proteins and DNA, causing different health conditions, including infertility. The role of oxidative stress in female infertility has not received as much attention as male infertility, and research is still limited. This study explored whether the overproduction of free radicals can impact the success of in vitro fertilization (IVF) treatment using several biological markers such as hydrogen peroxide, catalase, and total antioxidant capacity. Our findings revealed that the high antioxidant levels in the fluid surrounding the egg were linked with a high fertilization rate. Additionally, oxidative stress status in couples was associated negatively with several reproductive hormones and smoking status. Biomarkers of oxidative stress and DNA damage might have potential applications in evaluating IVF patients' clinical characteristics such as causes of infertility, hormonal profile, fertilization rate, implantation and live birth.

Key Words:
hormones oxidative stress

https://raf.bioscientifica.com

https://doi.org/10.1530/RAF-20-0062 (c) 2021 The authors Published by Bioscientifica Ltd

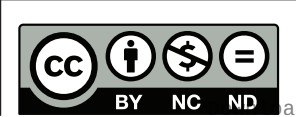

This work is licensed under a Creative Commons Attribution-NonCommercial-NoDerivatives 4.0 International License.

ded from Bioscientifica.com at 04/26/2023 12:50:10AM 


\section{Introduction}

Oxidative stress is the result of an imbalance between reactive oxygen species (ROS) formation and enzymatic and non-enzymatic antioxidants, which may play a complex role in the pathogenesis of a range of human diseases, including neurodegenerative, cardiovascular, metabolic disorders, and cancer (Raghunath et al. 2018). The role of ROS in the etiology of male and female infertility has also been reported (Agarwal et al. 2012a, 2014). Some of the factors that have been implicated in ROS production are related to the modern lifestyle, for example, smoking, unhealthy eating habit, and lack of exercise, as these factors are associated with excess inflammation, oxidative stress, and ultimately DNA damage (Moller et al. 2014, da Silva 2016). Additionally, many environmental pollutants can induce ROS production, and thereby inducing a state of oxidative stress, which can impair testicular function (Asadi et al. 2017) and contribute to oocyte dysfunction (Devine et al. 2012) and also cause epigenetic modifications of gametes (Dattilo et al. 2016).

ROS such as superoxide anions, hydrogen peroxide $\left(\mathrm{H}_{2} \mathrm{O}_{2}\right)$, and the hydroxyl free radical are formed as by-products of oxygen metabolism (Sharma et al. 2017). The presence of excess ROS can cause damage to lipids, proteins, and nucleotides (Freinbichler et al. 2011). Notably, ROS's overproduction has been found to significantly impact the success of in vitro fertilization (IVF) (Bedaiwy et al. 2012, Askoxylaki et al. 2013). A recent study revealed improved IVF outcomes in women under a moderate degree of oxidative stress (Rosen et al. 2019). Further, ROS measurement in seminal plasma has been suggested to have diagnostic and prognostic value in male infertility assessment (Venkatesh et al. 2011) since $30-80 \%$ of infertile men have elevated ROS levels (Agarwal \& Allamaneni 2011). DNA is one of ROS's most common targets, which has been associated with cellular transformation and genome instability. However, 8-oxo-2'-deoxyguanosine (8-OHdG) is widely used as a biomarker for oxidative modifications of DNA bases (Lee \& Pervaiz 2011). Additionally, 8-OHdG is considered as a specific, quantitative biomarker to determine the extent of the oxidative DNA damage caused by ROS in human sperm (Shen \& Ong 2000), as oxidative damage is known to reduce spermatogenesis and sperm function, and eventually, lead to male infertility (Agarwal et al. 2014, Guerriero et al. 2014). Sperm DNA damage is a helpful biomarker for diagnosing male infertility and predicting assisted reproduction outcomes (Lewis et al. 2013, Simon et al. 2017). The alkaline comet assay has been proven to be a relatively simple and versatile tool for assessing DNA damage and determining the efficacy of DNA repair mechanisms (Gunasekarana et al. 2015). Oxidative stress might disturb the hypothalamus-pituitary-gonadal axis functions via its action on the reproductive hormones (Darbandi et al. 2018). For example, one study has shown that ROS generation induced by lead poisoning resulted in testosterone (T) suppression via impairment of the hypothalamus-pituitary-gonadal axis (Gandhi et al. 2017).

ROS role in female infertility has not received as much attention as in male infertility, and there is minimal research on the topic (Ruder et al. 2008). ROS might play an essential role in the initiation of apoptosis in antral follicles by depleting glutathione, which is usually required for male pronucleus formation at the time of fertilization and embryonic development to the blastocyst stage (Devine et al. 2012). Cumulus cells play an essential role in oocyte maturation, ovulation, and fertilization (Zhuo $\&$ Kimata 2001). Animal studies have found the cumulusoocyte complex to be useful for testing the genotoxicity of environmental agents with the comet assay (Einaudi et al. 2014, Greco et al. 2015). However, these findings have not been confirmed in human studies.

Furthermore, oxidative stress may impact the production of steroid hormones, such as folliclestimulating hormone $(\mathrm{FSH})$ and estradiol $\left(\mathrm{E}_{2}\right)$, produced by granulosa cells, and subsequently lower the quality of oocytes and the success rate of IVF outcome (Seino et al. 2002, Avila et al. 2016).

In the present study, we measured several biomarkers of oxidative stress in follicular fluid and seminal plasma and DNA damage in sperm and granulosa cells in 599 couples undergoing IVF treatment to assess the potential relationships of these biomarkers with reproductive hormones, smoking status, and IVF outcomes.

\section{Materials and methods}

\section{Study population}

A total of 599 women and their male partners who were undergoing IVF treatment at King Faisal Specialist Hospital and Research Centre (KFSH\&RC), Riyadh, Saudi Arabia were enrolled between 8 March 2015 and 15 January 2017 for treatment. The women's age range was 19-48 years old, and their male partners' age range was 25-73 years old. The main reasons for IVF treatment were female factors (16.4\%), male factors $(47.7 \%)$, combined male and female factors (14.7\%), and preimplantation genetic diagnosis

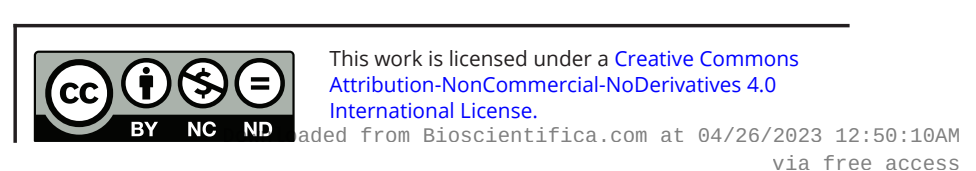


(PGD) (14.4\%). The cause of infertility was not evident in $6.8 \%$ of the cases. The couples signed an informed consent form at the recruitment time approved by the KFSH\&RC Research Ethics Committee (RAC\#2132024). Urine, follicular fluid, and seminal plasma samples were collected from each couple. Figure 1 depicts the data for the study population.

\section{Sample collection}

\section{Spot urine samples}

All the enrolled couples provided their urine samples during clinic visits either in the morning or afternoon in a sterile $100 \mathrm{~mL}$ polypropylene cup 2 to 3 days before follicle aspiration. The samples were aliquoted and stored at $-20^{\circ} \mathrm{C}$ until the analysis of cotinine (COT).

\section{Follicular fluid samples}

Follicular aspirates without major blood contamination were obtained from each of the female participants. The follicular aspirate was poured into $60 \mathrm{~mm}$ Falcon dishes (Beckton Dickinson Labware, Franklin Lakes, New Jersey, USA), and cumulus-oocyte complexes were transferred to another dish containing Multipurpose Handling Medium (Irvine Scientific, Santa Ana, CA). The remaining granulosa cells and follicular fluids, which are usually discarded after this process, were separated and transferred to $1.5 \mathrm{~mL}$ vials and $15 \mathrm{~mL}$ conical tubes, respectively. The follicular fluid samples were centrifuged at $800 \boldsymbol{g}$ for $5 \mathrm{~min}$, and the supernatant was collected into $2 \mathrm{~mL}$ labeled polypropylene plastic tubes and stored at $-20^{\circ} \mathrm{C}$ for malondialdehyde (MDA), 8-OHdG and ROS assays, as

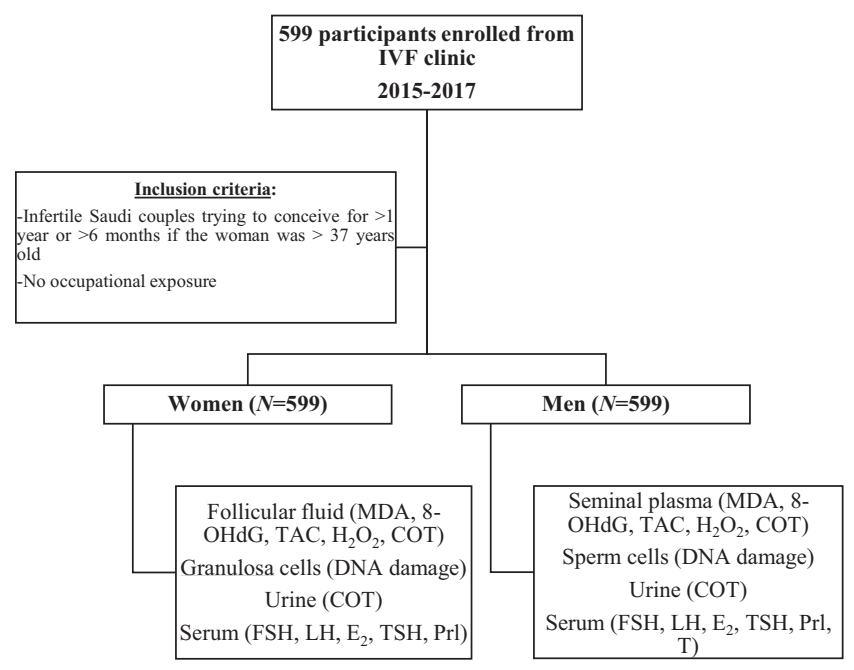

Figure 1 Flow chart of the study population. well as COT assay. The granulosa cells were transferred into $1.5 \mathrm{~mL}$ cryogenic vials (Corning ${ }^{\circledR}$ Incorporated, NY, USA) and centrifuged at $800 \boldsymbol{g}$ for $5 \mathrm{~min}$ to separate the supernatant. The pellet was re-suspended in $150 \mu \mathrm{L}$ of calcium- and magnesium-free PBS (Sigma Chemical Co.), and the vials were immediately placed in isopropanol progressive Nalgene ${ }^{\circledR}$ Mr Frosty freezing container (SigmaAldrich) at $-80^{\circ} \mathrm{C}$ overnight, immersed in liquid nitrogen after $24 \mathrm{~h}$, and used later for the comet assay.

\section{Semen samples}

On the same day, oocyte retrieval was performed, semen samples were collected by masturbation (following the semen collection instructions given to the patients) and allowed to liquefy for 15-30 $\mathrm{min}$ at room temperature. Before the sample preparation for IVF/intracytoplasmic sperm injection (ICSI), routine semen parameters were assessed. The remaining semen samples (250-500 $\mu \mathrm{L})$, which are usually discarded, were placed in a $15 \mathrm{~mL}$ polypropylene tube within $30 \mathrm{~min}$ of collection. Seminal plasma was separated from spermatozoa by centrifugation at $800 \boldsymbol{g}$ for $5 \mathrm{~min}$ and stored at $-80^{\circ} \mathrm{C}$ for MDA, 8-OHdG, ROS and COT assays. The sperm pellets were transferred into $1.5 \mathrm{~mL}$ cryogenic vials and immediately placed in isopropanol progressive Nalgene ${ }^{\circledR} \mathrm{Mr}$ Frosty freezing container at $-80^{\circ} \mathrm{C}$ overnight and stored in liquid nitrogen the previous day before they were processed for the comet assay.

\section{Analytical methods}

\section{Hormonal parameters}

As part of the routine IVF procedure, a blood sample was drawn from each woman on the 3rd day of the menstrual cycle (follicular phase) for analysis of FSH, luteinizing hormone (LH), thyroid-stimulating hormone (TSH), $\mathrm{E}_{2}$ and prolactin (Prl). A male hormonal profile, including $\mathrm{LH}, \mathrm{FSH}, \mathrm{E}_{2}, \mathrm{TSH}, \mathrm{Prl}$, and T, was requested only in male infertility cases at the initial clinical visit. The data for these parameters were obtained from the patient medical records. In the case of normozoospermic men for whom the hormonal profile was not available in their medical records, a $4 \mathrm{~mL}$ venous blood sample was drawn on the day of oocyte retrieval into Vacutainer ${ }^{\circledR}$ tubes (Becton, Dickinson, and Co., NJ, USA) without anticoagulant and the serum fraction was analyzed at the Clinical Biochemistry, Pathology and Laboratory Medicine Department, KFSH\&RC.

This work is licensed under a Creative Commons Attribution-NonCommercial-NoDerivatives 4.0 International License. 


\section{Oxidative stress and DNA damage biomarkers}

Total antioxidant capacity (TAC), catalase (CAT) activity, and hydrogen peroxide $\left(\mathrm{H}_{2} \mathrm{O}_{2}\right)$ /peroxidase were measured using the OxiSelect ${ }^{\mathrm{TM}}$ Total Antioxidant Capacity Assay Kit (Cell Biolabs, San Diego, USA), DetectX Catalase Fluorescence Activity Kit (Arbor Assays, MI, USA); and OxiSelect $^{\mathrm{TM}}$ Hydrogen Peroxide/Peroxidase Assay Kit (Fluorometric), respectively. The 8-OHdG levels were measured in follicular fluid and seminal plasma using the HT 8-oxodG kit II (Trevigen Inc., Gaithersburg, USA). According to the manufacturer's instructions, all assays were performed, and absorbance was read using an automated ELISA microplate reader. The Anthos Zenyth 3100 Multimode Detector (Zenyth, Salzburg, Austria) was used for CAT and $\mathrm{H}_{2} \mathrm{O}_{2}$ /peroxidase assay. TAC and 8-OHdG were measured using Biotek ${ }^{\mathrm{TM}} \mathrm{EL} \times 800^{\mathrm{TM}}$ Absorbance Microplate Readers (Winooski, USA). Finally, MDA assay was performed using the Alliance Waters HPLC 2695 system and a multi-fluorescence detector (Model 2475) as previously described (Al-Saleh et al. 2007).

\section{Single-cell gel electrophoresis assay (comet assay)}

The alkaline comet assay was performed in granulosa and sperm cells, according to the modified methods of Singh et al. (1988) and Lindley et al. (2001). Images were taken at a magnification of $20 \times$ with a fluorescence optical microscope (Nikon Eclipse TI-E; Nikon, Japan) equipped with excitation $(465 \mathrm{~nm})$ and barrier $(595 \mathrm{~nm})$ filters. Twenty-five cells per sample were randomly evaluated using the Comet assay IV Windows software with a monochrome CCD IEEE1394 FireWire video camera (Perceptive Instruments, Halstead, UK). Five parameters were measured: head length (HL), tail length (TL), head intensity (TI), percentage of DNA tail (\% DNA tail), and tail moment (TM). The percentage of DNA in the tail multiplied by the distance between the center of the tail and head represents TM that was used in the present study as an indicator of DNA damage.

A limitation of the comet assay is the lack of standardized protocol that hinders the interpretation and comparison of the results with other studies (Collins 2015).

\section{COT}

The Cotinine ELISA immunoassay kit (Bio-Quant COTININE Direct ELISA, San Diego, USA) was used to measure COT in urine, follicular fluid, and seminal plasma as a biomarker of nicotine exposure. A $10 \mu \mathrm{L}$ sample was aliquoted in duplicate into a 96-well microtiter plate and processed according to the manufacturer's protocol. Absorbance was measured at $\mathrm{OD}_{450}$ using a Biotek ${ }^{\mathrm{TM}} \mathrm{EL}$ $\times 800^{\mathrm{TM}}$, Absorbance Microplate Reader (Winooski, USA).

\section{Main study outcomes and potential confounders}

In this study, we examined the association of oxidative stress and DNA damage markers with primary IVF outcomes such as fertilization rate (the percentage of the number of oocytes with $2 \mathrm{PN}$ divided by the total number of oocytes retrieved, and achieved fertilization rate was $>50 \%$ ), biochemical pregnancy (positive $\beta$-human chorionic gonadotropin in urine and serum on day 14 with no evidence of gestational sac or fetal heartbeat to indicate continued pregnancy), clinical pregnancy (the presence of gestational sacs with fetal heartbeat confirmed by ultrasound) and live birth (successful delivery of one or more live neonates after 24 weeks of gestation). Each endpoint (fertilization rate, biochemical pregnancy, clinical pregnancy, and live birth) was dichotomized as a binary variable. A failure group represented women with a fertilization rate $\leq 50 \%$, no biochemical pregnancy (negative $\beta$-human chorionic gonadotropin test), no clinical pregnancy (loss of gestational sac on ultrasound) or no live birth (unsuccessful delivery of a live neonate).

Of the 599 couples, 422 (70.5\%), 196 (32.7\%), 161 (26.9\%) and 136 (22.7\%) achieved fertilization (>50\%), biochemical pregnancy, clinical pregnancy and live birth, respectively.

Potential confounders associated with IVF outcomes and/or oxidative stress, such as age, BMI, causes of infertility, pollution, socioeconomic status, and smoking, were selected based on previous reports (Benedict et al. 2011, Moller et al. 2014, Black et al. 2016, Kumar et al. 2018).

\section{Statistical analysis}

The data are presented as mean, median, and geometric mean. All parameters were naturally logarithm transformed (ln) to obtain a normal distribution for analysis. Pearson's correlation coefficients were calculated to determine the associations between the studied parameters. Separate multivariate linear regression models were established for each of the reproductive hormones and smoking parameters, which were used as continuous variables that were predicted by the ln-concentration of each of https://raf.bioscientifica.com

https://doi.org/10.1530/RAF-20-0062 (c) 2021 The authors Published by Bioscientifica Ltd
This work is licensed under a Creative Commons Attribution-NonCommercial-NoDerivatives 4.0 International License. International License.
aded from Bioscientifica.com at 04/26/2023 12:50:10AM 
the oxidative stress and DNA damage variables, with and without adjusting for confounders (age, BMI, causes of infertility, educational level, total monthly family income, regional distribution of residence and urinary COT levels). Results are expressed as the value of $\beta$ standardized regression coefficients as estimates of effect, with 95\% $\mathrm{CI}$ and $P$ values used to assess statistical significance. We evaluated collinearity with the variance inflation factor (VIF) in the linear regression analyses. This did not exceed 10 , the commonly used cut-off for collinearity problem, mainly when correlations between variables are not highly correlated (O'Brien 2007, Lavery et al. 2019). In our study, the correlations between variables were either small or moderate, and VIF values were less than 2 .

Since the prevalence of achieving IVF endpoints (fertilization rate $>50 \%$, biochemical pregnancy, clinical pregnancy, and live birth) was high ( $>10 \%)$ in our study, we used log-binomial multivariate regression models to estimate the relative risk (RR) and 95\% CI as an alternative approach to logistic regression (Barros and Hirakata, 2003). We modeled the association between each binary IVF outcome and each oxidative stress and DNA damage parameter as a continuous variable (ln-transformed) after adjusting for potential confounders. Since hormonal abnormalities may contribute to infertility and unsuccessful IVF outcome (Vannuccini et al. 2016), we repeated the log-binomial regression analysis after including reproductive hormones as a potential confounder. Principal component analysis (PCA) was applied with varimax rotation to identify the main clusters of reproductive hormones in women and their male partners. The choice of principal components (PCs) was based on their eigenvalue: PCs with an eigenvalue greater than 1 were selected. The adequacy of PCA was verified using the Kaiser-Meyer-Olkin value, which should be higher than 0.5 , and significance according to Bartlett's test. Factor loading $\geq 0.30$ was set as the criterion for parameter retention. PCA yielded two components that explained $54.538 \%$ of the total variance in women's reproductive hormones with positive loadings for PC1 (FSH, LH, and $\mathrm{E}_{2}$ ) and PC2 (TSH and Prl). In the case of the male participants, PCA identified three components that explained $69.413 \%$ of the total variance in reproductive hormones, with positive loadings for PC1 (FSH and LH and $\left.\mathrm{E}_{2}\right)$ and PC2 ( $\mathrm{E}_{2}$ and $\left.\mathrm{T}\right)$ but negative loadings for PC3 (TSH and Prl).

Significance was selected at $P<0.05$, and all calculations were performed using IBM SPSS Statistics for Windows, version 20.0 (IBM Corp.).

\section{Results}

Oxidative stress biomarkers, reproductive hormones, and smoking

The general characteristics of the 599 couples enrolled in this study are presented in Table 1. Biomarkers of oxidative stress (MDA, 8-OHdG, CAT, $\mathrm{H}_{2} \mathrm{O}_{2}$, and TAC) in seminal plasma and follicular fluid, DNA damage (HL, HI, TL, TI, and TM) in sperm and granulosa cells, and smoking (COT) in urine, follicular fluid, and seminal plasma are presented in Table 2. 8-OHdG, CAT, $\mathrm{H}_{2} \mathrm{O}_{2}$, and TAC were detected in all follicular fluid samples. In contrast, only CAT and $\mathrm{H}_{2} \mathrm{O}_{2}$ were detected in all seminal plasma samples. MDA was determined in 96.8 and $87.9 \%$ of follicular fluid and seminal plasma samples, respectively. 8-OHdG and TAC were found in 99.4 and $99.2 \%$ of seminal plasma samples, respectively.

\%DNA tail, TM, and TL are the most frequently used comet parameters for assessing genotoxicity because of their ability to measure DNA damage (Hartmann \& Speit 1997, Lee \& Steinert 2003, Kumaravel et al. 2009). Strong correlations were found between TL and \%DNA tail $(r=0.778)$ and TM $(r=0.868)$ and between TM and $\%$ DNA tail $(r=0.985)(P<0.001$ for all $)$ in granulosa cells from women. In sperm cells, strong correlations were detected between TL and \%DNA tail $(r=0.617)$ and TM $(r=0.772)$ and between TM and \%DNA tail $(r=0.974)(P$ $<0.001$ for all). In this study, TM was chosen for statistical evaluation as it provides the most stable estimates of DNA damage because of its uniformity in quantile dispersions (Lee et al. 2004).

COT levels were detected in more than $90 \%$ of urine samples from both women and their male partners. However, COT was detected in 49.3\% (283) and 52.7\% (77) of follicular fluid and seminal plasma samples, respectively. A $50 \mu \mathrm{g} / \mathrm{L}$ cut-off of COT level in urine was employed to distinguish active smokers from nonsmokers (Jarvis et al. 1987). Though the authors used gas chromatography for urinary COT analysis, a similar cut-off was determined with the ELISA method (Balhara et al. 2012). The highest COT levels were seen in urine, yet a similar magnitude was observed in other biological matrices such as blood and semen (Vine et al. 1993). In the present study, 349 (58.3\%) men and 34 (5.7\%) women had urinary COT level above $50 \mu \mathrm{g} / \mathrm{L}$. There is no cut-off for COT in the seminal plasma or follicular fluid to the best of our knowledge. However, Fuentes et al. (2010) found that COT in recent smokers' follicular fluid was $>10 \mu \mathrm{g} / \mathrm{L}$, whereas nonsmokers' levels were undetectable. Only ten $(1.7 \%)$ of our women had 


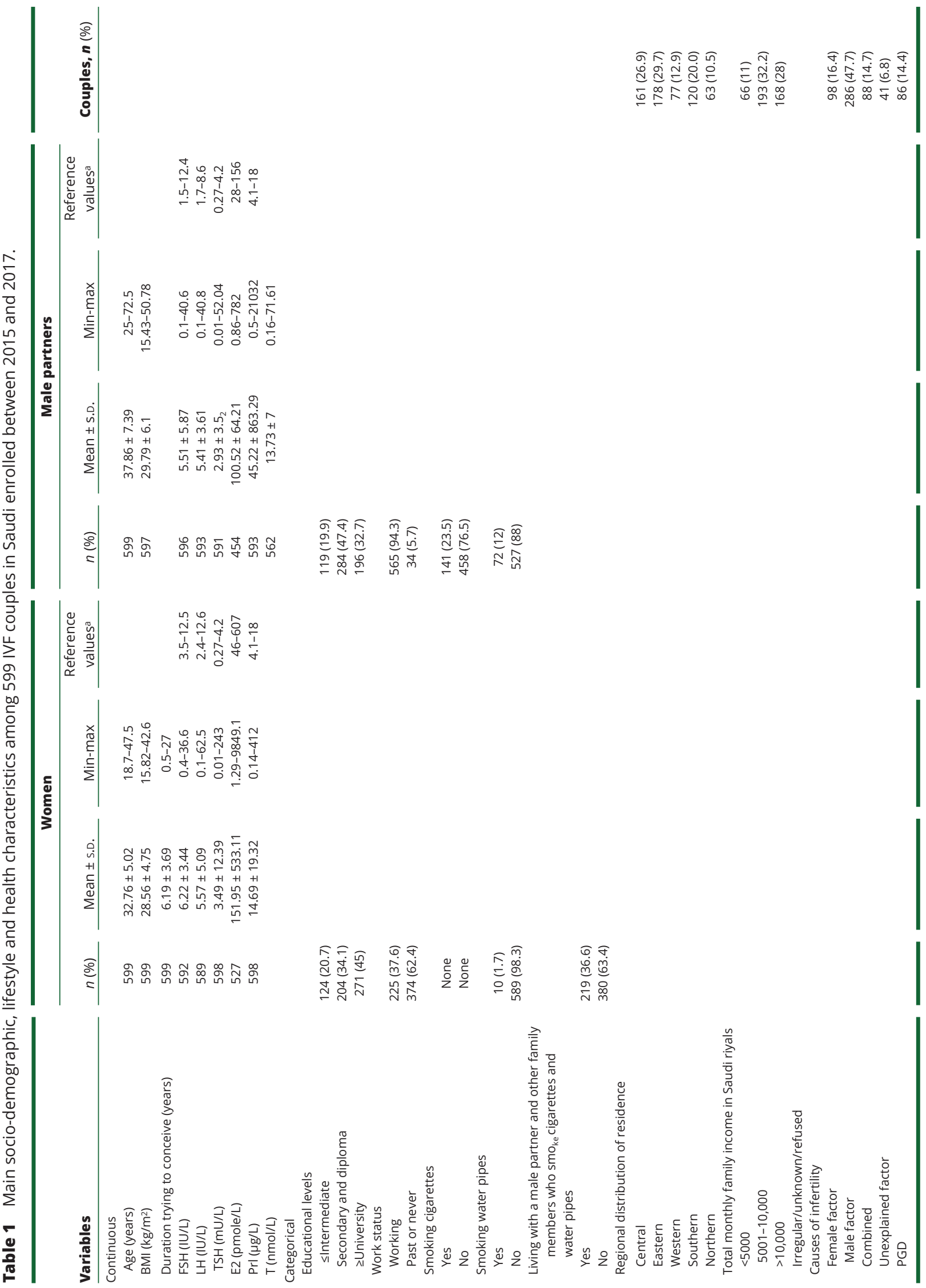




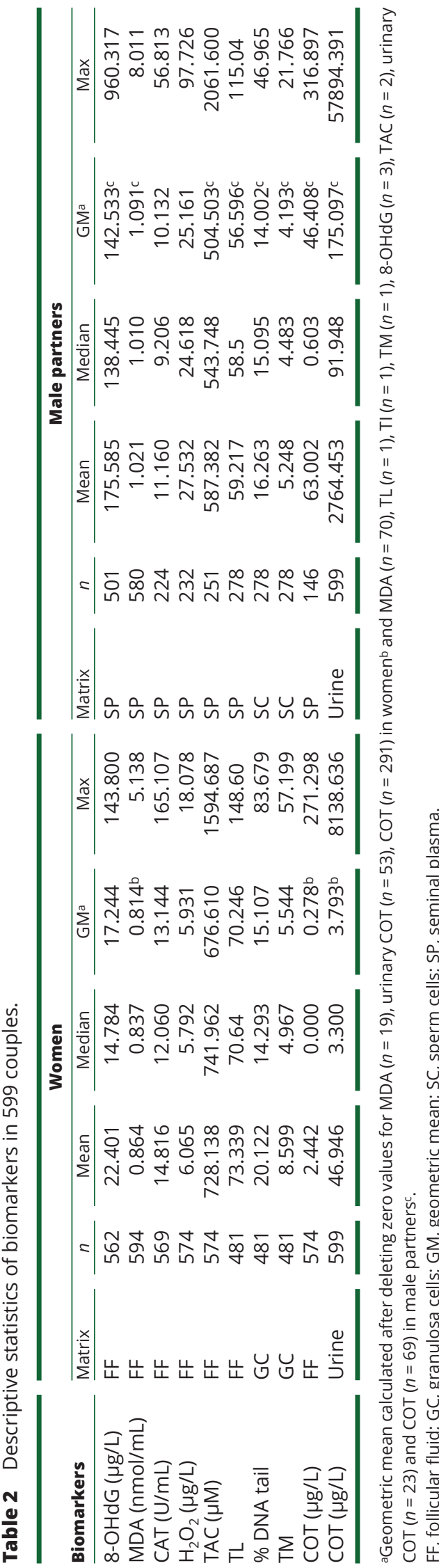

https://raf.bioscientifica.com https://doi.org/10.1530/RAF-20-0062 (c) 2021 The authors Published by Bioscientifica Ltd
COT in follicular fluid above $10 \mu \mathrm{g} / \mathrm{L}$ in the range between 19.37 and $271.3 \mu \mathrm{g} / \mathrm{L}$. Terzioğlu et al. (2016) found COT levels in seminal plasma of nonsmokers and passive smokers were $<10 \mu \mathrm{g} / \mathrm{L}$. In our study, 61 (41.8\%) men had COT higher than $10 \mu \mathrm{g} / \mathrm{L}$ in the range between 11.7 and $316.9 \mu \mathrm{g} / \mathrm{L}$. Both Fuentes et al. (2010) and Terzioğlu et al. (2016) measured COT using the ELISA method. ELISA is considered a practical alternative screening assay to chromatographic methods. Kuo et al. (2002) found that the levels of urinary COT measured by HPLC were strongly correlated $(r>0.9)$ with levels measured using ELISA or gas chromatography.

Statistically significant inter-correlations between the tested biomarkers are shown in Table 3. The data indicate the presence of oxidative stress-related biomarkers mechanisms in the participating couples.

\section{Associations of biomarkers of oxidative stress/DNA damage with reproductive hormones and smoking}

We first examined the crude relationship between oxidative stress and DNA damage biomarkers and reproductive hormones in women and their male partners (Table 4). The levels of LH in women was positively associated with the 8-OHdG $(P=0.014)$ and CAT $(P=0.001)$ levels in follicular fluid, but it was negatively associated with TM in granulosa cells $(P<0.001)$. The TSH and $\mathrm{E}_{2}$ levels were inversely related to follicular fluid $\mathrm{H}_{2} \mathrm{O}_{2}$ levels $(P=0.007)$ and TM in granulosa cells $(P=0.029)$, respectively. TAC in follicular fluid was inversely associated with $\operatorname{Prl}(P=0.045)$. In women's urine, COT was positively correlated with follicular CAT levels $(P=0.045)$. Additionally, the follicular fluid COT level was positively correlated with the levels of follicular fluid $\mathrm{H}_{2} \mathrm{O}_{2}(P=0.05)$ and TM in granulosa cells $(P=0.012)$. In the male partners, the FSH and LH levels were inversely associated with seminal MDA levels $\left(P<0.001\right.$ and $P<0.039$, respectively). While the $\mathrm{E}_{2}$ levels were positively correlated with seminal CAT levels $(P=0.047), \mathrm{T}$ was inversely correlated with seminal TAC levels $(P=0.024)$. In the male partners' urine samples, the COT levels were positively and inversely correlated with CAT's seminal plasma levels $(P=0.035)$ and $\mathrm{H}_{2} \mathrm{O}_{2}$ $(P=0.007)$. None of the oxidative stress and DNA damage parameters were significantly correlated with COT in seminal plasma.

We adjusted all the regression models in Table 4 for age, BMI, ln-COT in urine, educational level, total family income, and cause of infertility. In women, LH remained significantly and positively associated with 8-OHdG $(P=0.011)$ and CAT $(P=0.003)$ in follicular fluid, but

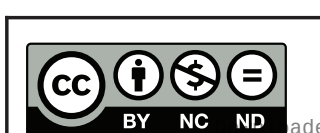

This work is licensed under a Creative Commons Attribution-NonCommercial-NoDerivatives 4.0 International License. 
Table 3 Inter-correlations among log-transformed oxidative stress biomarkers in women and their male partners (the values in bold denote significant correlations).

\begin{tabular}{|c|c|c|c|c|c|c|}
\hline & MDA & 8-OHdG & CAT & $\mathrm{H}_{2} \mathrm{O}_{2}$ & TAC & TM \\
\hline \multicolumn{7}{|c|}{ Women } \\
\hline \multicolumn{7}{|c|}{ 8-OHdG ( $\mu \mathrm{g} / \mathrm{L})$} \\
\hline$r$ & -0.074 & & & & & \\
\hline$P$ & 0.082 & & & & & \\
\hline$n$ & 562 & & & & & \\
\hline \multicolumn{7}{|c|}{ CAT $(\mathrm{U} / \mathrm{mL})$} \\
\hline$r$ & -0.018 & $0.114^{* *}$ & & & & \\
\hline$P$ & 0.671 & 0.007 & & & & \\
\hline$n$ & 569 & 556 & & & & \\
\hline \multicolumn{7}{|c|}{$\mathrm{H}_{2} \mathrm{O}_{2}(\mu \mathrm{g} / \mathrm{L})$} \\
\hline$r$ & $-0.140^{\star \star}$ & $-0.216^{\star *}$ & $0.131^{\text {** }}$ & & & \\
\hline$p$ & 0.001 & $<0.001$ & 0.002 & & & \\
\hline$n$ & 574 & 560 & 568 & & & \\
\hline \multicolumn{7}{|c|}{$\mathrm{TAC}(\mu \mathrm{M})$} \\
\hline$r$ & $0.177^{\star \star \star}$ & -0.043 & $0.101^{*}$ & 0.041 & & \\
\hline$P$ & $<0.001$ & 0.312 & 0.016 & 0.332 & & \\
\hline$n$ & 574 & 560 & 568 & 573 & & \\
\hline \multicolumn{7}{|l|}{ TM } \\
\hline$r$ & $0.147^{\star \star}$ & $-0.142^{\star *}$ & -0.038 & 0.038 & $0.111^{*}$ & \\
\hline$P$ & 0.001 & 0.002 & 0.410 & 0.403 & 0.015 & \\
\hline$n$ & 481 & 468 & 476 & 480 & 480 & \\
\hline \multicolumn{7}{|c|}{ Male partners } \\
\hline \multicolumn{7}{|c|}{ 8-OHdG $(\mu \mathrm{g} / \mathrm{L})$} \\
\hline$r$ & $0.179^{\star *}$ & & & & & \\
\hline$P$ & $<0.001$ & & & & & \\
\hline \multirow{2}{*}{\multicolumn{7}{|c|}{ CAT $(\mathrm{U} / \mathrm{mL})$}} \\
\hline & & & & & & \\
\hline$r$ & 0.127 & $0.209^{* *}$ & & & & \\
\hline$P$ & 0.058 & 0.002 & & & & \\
\hline$n$ & 224 & 222 & & & & \\
\hline \multicolumn{7}{|c|}{$\mathrm{H}_{2} \mathrm{O}_{2}(\mu \mathrm{g} / \mathrm{L})$} \\
\hline$r$ & $0.306^{* *}$ & $0.194^{\star *}$ & 0.107 & & & \\
\hline$P$ & $<0.001$ & 0.003 & 0.171 & & & \\
\hline$n$ & 232 & 227 & 164 & & & \\
\hline \multicolumn{7}{|c|}{$\mathrm{TAC}(\mu \mathrm{M})$} \\
\hline$r$ & 0.088 & 0.083 & 0.031 & $0.250^{\star \star \star}$ & & \\
\hline$P$ & 0.167 & 0.192 & 0.718 & 0.002 & & \\
\hline$n$ & 249 & 246 & 139 & 150 & & \\
\hline \multicolumn{7}{|l|}{ TM } \\
\hline$r$ & 0.076 & $0.213^{\star \star}$ & -0.061 & $0.194^{*}$ & -0.069 & \\
\hline$P$ & 0.209 & $<0.001$ & 0.504 & 0.022 & 0.407 & \\
\hline$n$ & 276 & 271 & 124 & 139 & 148 & \\
\hline
\end{tabular}

*Correlation is significant at the 0.05 level (two-tailed); ${ }^{* *}$ Correlation is significant at the 0.01 level (two-tailed).

inversely correlated with TM in granulosa cells $(P<0.001)$. Further, TSH maintained an inverse correlation with $\mathrm{H}_{2} \mathrm{O}_{2}$ in follicular fluid $(P=0.004)$, but it became significantly and positively associated with 8 -OHdG $(P=0.022) . \mathrm{E}_{2}$ in follicular fluid remained negatively associated with TM in granulosa cells $(P=0.032)$. In contrast, Prl and TAC's relationship in follicular fluid became insignificant $(P=0.071)$ after adjusting the model for confounders. In the male partners, FSH remained negatively associated with MDA $(P<0.001)$. On the other hand, LH and MDA's relationship and between E2 and CAT disappeared after adjusting for confounders. We also observed positive and significant correlations between $\mathrm{T}$ and MDA $(P=0.026)$ that were not observed in the crude regression analysis. About the relationship between biomarkers of oxidative stress and DNA damage and COT in urine, follicular fluid, and seminal plasma after adjusting for confounders, the associations between follicular fluid CAT and urinary COT in women remained significant $(P=0.022)$, as did the correlation between follicular COT and $\mathrm{H}_{2} \mathrm{O}_{2}(P=0.047)$

This work is licensed under a Creative Commons Attribution-NonCommercial-NoDerivatives 4.0 International License. 


\section{|}

\begin{tabular}{|c|}
\hline 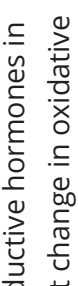 \\
\hline
\end{tabular}

क人

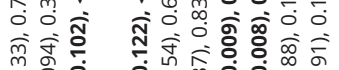

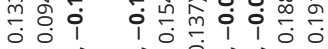

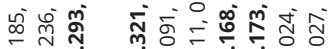

iiำ

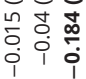

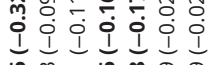

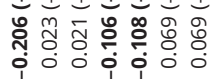

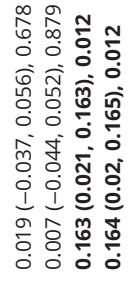

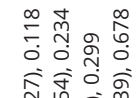

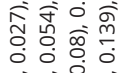

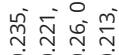

i. I i i

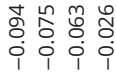

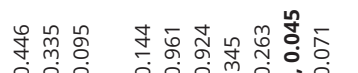

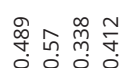

席窟要

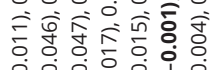

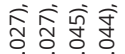

mign

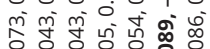

min

i i i i

$\begin{array}{ll}1 & 1 \\ 0 & 0 \\ 0 & 0 \\ 0 & 0\end{array}$

i i i o o o.

o. 이이

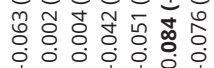

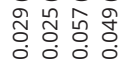

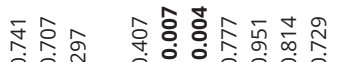

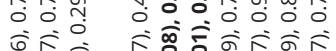

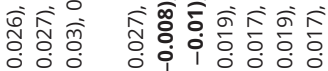

岗各

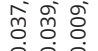

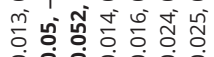

字产绍势

iकi

IIIIII

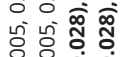

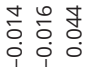

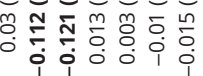

iliej

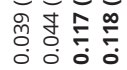

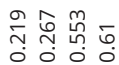

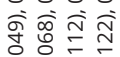

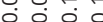

ㄱำ

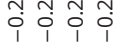

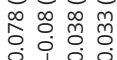

4

产

1.

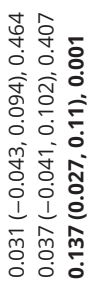

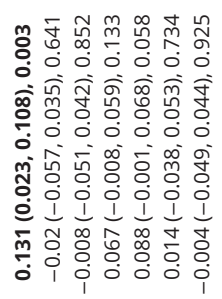

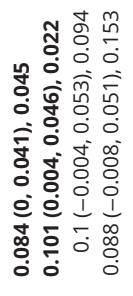

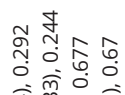

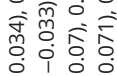

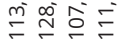

iiㅗㅇㅣ

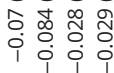

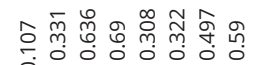

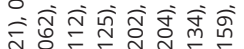

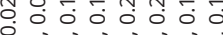

i

i íioi i i i

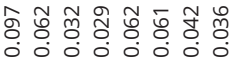

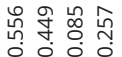

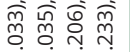

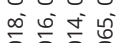

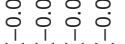

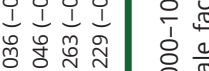

1 1 11001 i

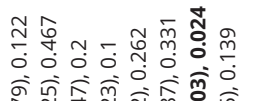

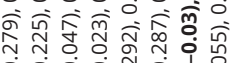

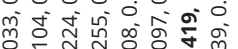

ió o o o o

o.

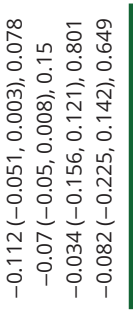

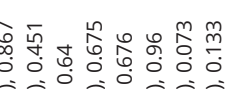

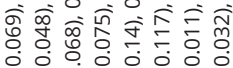

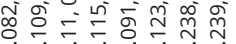

ioisioisis

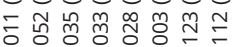

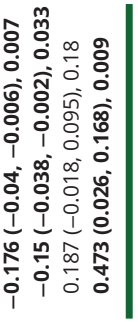

1.

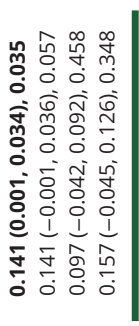

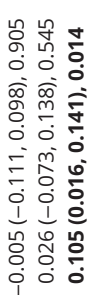

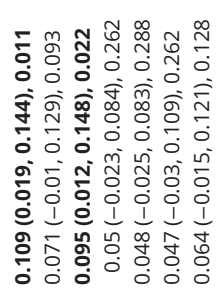

突

啇芒金旁

0

ह்

i i i i i i

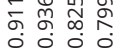

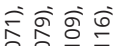

영ำ

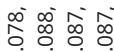

i. i cio

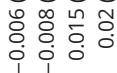

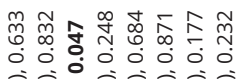

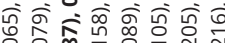

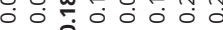

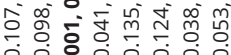

1

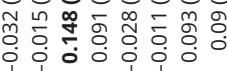

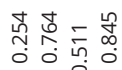

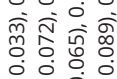

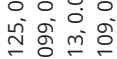

i.

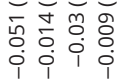

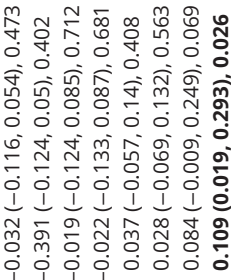

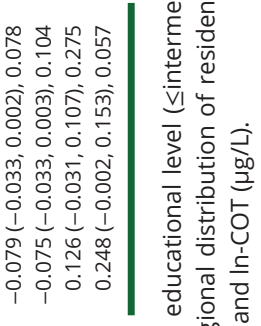

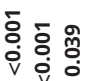

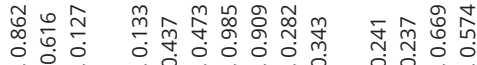

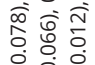

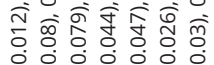

言宅市

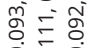

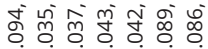

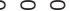

言言富

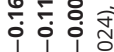

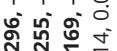

i i i

i i i i i i i

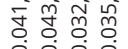

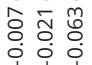

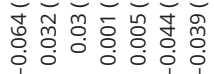

i i i i i

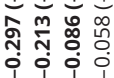

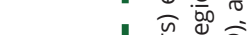

i1 i i

等

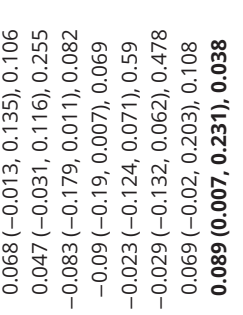

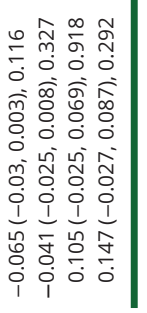

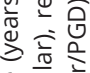

을

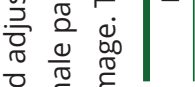
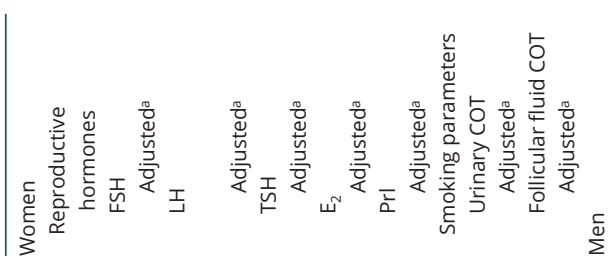

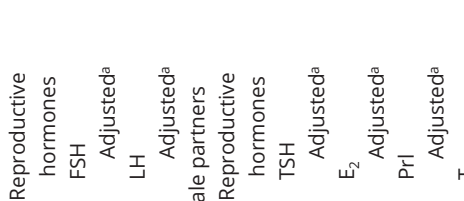

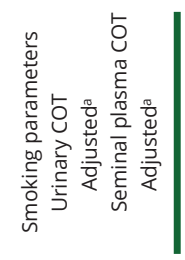

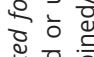

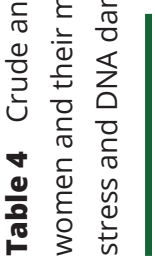

(c) 2021 The authors

Published by Bioscientifica Ltd 
and TM in granulosa cells $(P=0.012)$. In the male partners, seminal plasma $\mathrm{H}_{2} \mathrm{O}_{2}$ remained significantly associated with urinary COT $(P=0.033)$ and seminal COT $(P=0.009)$, although the latter correlation was not significant in the crude analysis.

\section{Association between oxidative stress and IVF outcomes}

As shown in Table 5, multivariate log-binomial regression analyses revealed that there was a significant decrease in the risk of poor fertilization rate $(\leq 50 \%)(R R=0.52$, 95\% CI $=0.331,0.817, P=0.005)$ and unsuccessful live birth $(\mathrm{RR}=0.592,95 \% \mathrm{CI}=0.377,0.93, P=0.023)$ in association with one-unit increase in the follicular fluid CAT level. After adjusting the model for hormonal factors, as represented by PC1 ( $\mathrm{FSH}, \mathrm{LH}$, and $\left.\mathrm{E}_{2}\right)$, a decrease in the risk of poor fertilization rate $(\leq 50 \%)$ was observed as a one-unit increase in the follicular fluid levels of CAT $(\mathrm{RR}=0.508,95 \% \mathrm{CI}=0.306,0.842, P=0.009)$ and $\mathrm{TAC}$ $(\mathrm{RR}=0.585,95 \% \mathrm{CI}=0.493,1.13, P=0.023)$, while the correlation between a decrease in the risk of unsuccessful live birth rate and per unit increase in the level of CAT in follicular fluid became insignificant $(R R=0.623$, 95\% $\mathrm{CI}=0.367,1.056, P=0.079)$. When the model was adjusted for PC2 (TSH and Prl), the risk of poor fertilization rate decreased in association with elevated follicular fluid levels of CAT $(\mathrm{RR}=0.479,95 \% \mathrm{CI}=0.289$, $0.792, P=0.004)$ and $\mathrm{TAC}(\mathrm{RR}=0.605,95 \% \mathrm{CI}=0.381$, $0.961, P=0.033)$. In contrast, the relationship between CAT levels in follicular fluid and low risk of unsuccessful live birth became significant $(\mathrm{RR}=0.59,95 \% \mathrm{CI}=0.349$, 0.995), $P=0.048)$. In the male partners, none of the associations were significant with and without adjusting for PC1 (FSH and LH), PC2 ( $\mathrm{E}_{2}$ and T), or PC3 (TSH, Prl, and $\mathrm{T}$ ). In Table 5, we only report the results for models adjusted with and without PC1, which showed the highest variability of $33.052 \%$ in women and $28.51 \%$ in their male partners.

\section{Discussion}

\section{Oxidative stress profile in couples}

Several researchers have used MDA levels in the follicular fluid as an index of lipid peroxidation and found it to be associated with polycystic ovary syndrome (Fatemi et al. 2017), endometriosis (de Lima et al. 2017), low response ovarian stimulation (Nunez-Calonge et al. 2016), anovulation (Kazemi et al. 2014), tubal infertility
(Singh et al. 2013) and embryo quality (Liu et al. 2021). Our mean MDA value in follicular fluid (0.864 nmol/ $\mathrm{mL}$ ) was slightly higher than those reported by Artimani et al. (2018) in women with polycystic ovary syndrome (0.77 nmol/mL) but lower than Uppangala et al. (2020)'s value of $3.76 \mathrm{nmol} / \mathrm{mL}$ in women with a poor ovarian response, Thaker et al. (2020)'s value of $1.76 \mathrm{nmol} / \mathrm{mL}$ in women with positive IVF outcome, and Kazemi (2015)'s value of $0.98 \mathrm{nmol} / \mathrm{mL}$ in anovulatory women. However, our MDA value represents all women that underwent IVF treatment, of which only 186 (31.3\%) of them had infertility problem (including those with combined male and female infertility factors). The MDA levels in the follicular fluid of women with infertility problems were $0.895 \mathrm{nmol} / \mathrm{mL}$, which was not significantly different from other women who have undergone IVF treatment $(0.850 \mathrm{nmol} / \mathrm{mL}), P=0.277$. The same was seen after excluding cases with combined infertility factors. Jozwik (1999) observed low lipid peroxidation in the follicular fluid that might be related to the presence of efficient antioxidant defense systems surrounding the oocyte before ovulation. However, since MDA was detected in $96.8 \%$ of the follicular fluid samples, it could be deduced that some level of oxidative stress in the follicles might have impacted the IVF outcomes.

The MDA in seminal plasma can reflect the degree of peroxidative damage to spermatozoa (Agarwal et al. 2014). In general, our MDA value $(1.02 \mathrm{nmol} / \mathrm{mL})$ was slightly higher than the value of $0.94 \mathrm{nmol} / \mathrm{mL}$ (infertile) reported by Colagar et al. (2009) but lower than many other studies (Collodel et al. 2015, Atig et al. 2017, Josarayi et al. 2017). Our seminal plasma MDA values represent all men who have undergone IVF treatment. The seminal plasma MDA levels in 358 (61.7\%) men with infertility problems $(1.0 \mathrm{nmol} / \mathrm{mL})$ (including those with combined male and female infertility factors) were significantly lower than others $(1.102 \mathrm{nmol} / \mathrm{mL})(P<0.001)$. The same results were seen after excluding cases with combined infertility; seminal plasma MDA levels were significantly lower in men with male infertility $(0.976 \mathrm{nmol} / \mathrm{mL})$ vs others $(1.098 \mathrm{nmol} / \mathrm{mL})$ with $P<0.001$. Similar results were reported by Layali et al. (2015), though most of the literature indicated higher seminal plasma MDA in infertile men (Agarwal et al. 2016). MDA in semen can be influenced by smoking (Chari \& Colagar 2011), and $23.5 \%$ of men in the present study were smokers. After the smokers were excluded, the results remained the same: infertile men had significantly higher MDA levels than normozoospermic men. Additionally, sufficient antioxidant levels might lower the seminal plasma MDA

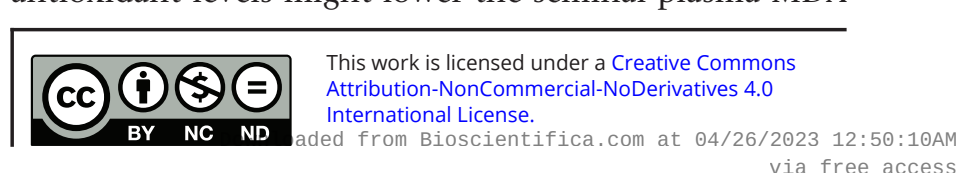




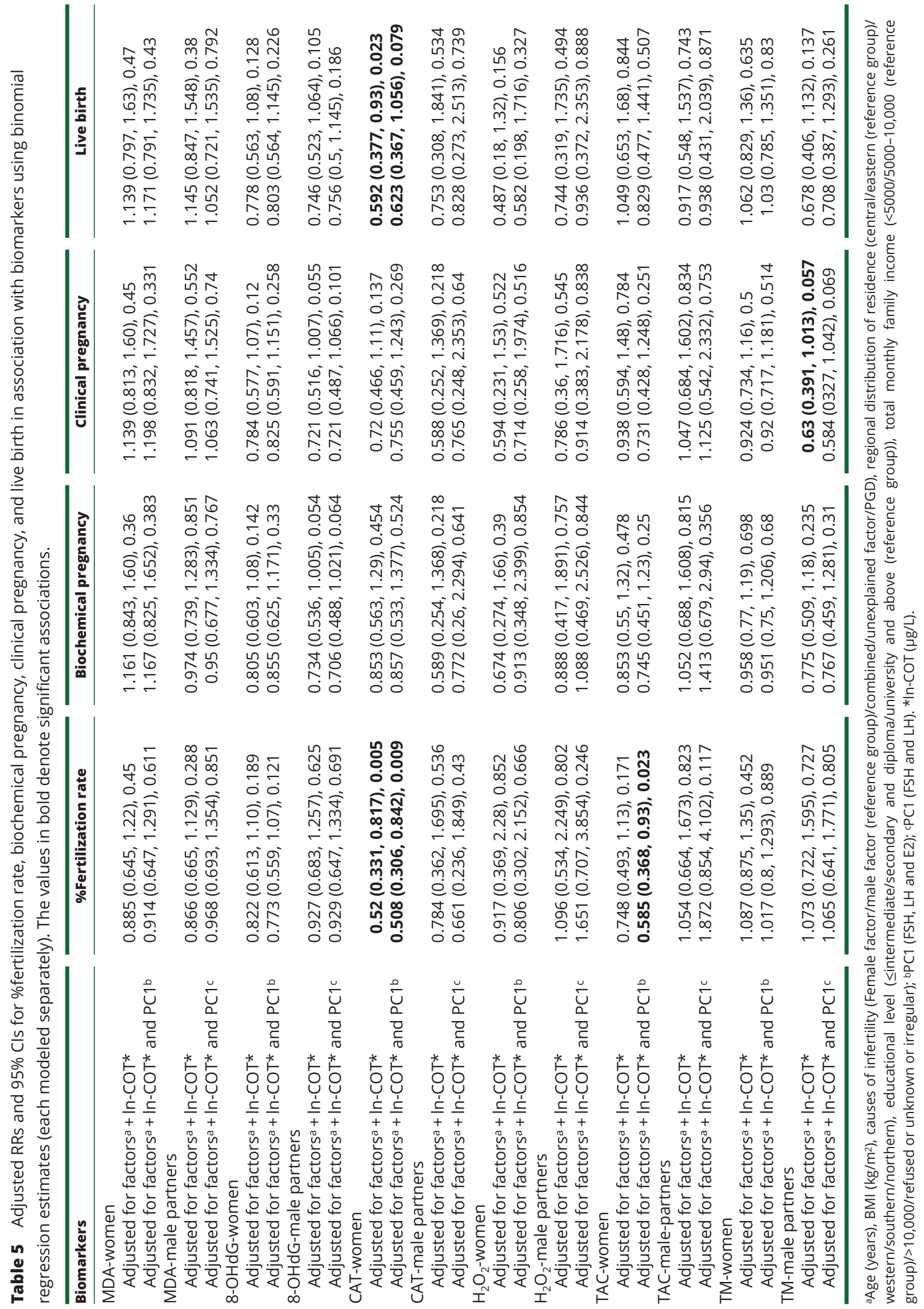


levels in infertile men (Agarwal \& Sekhon 2011). One should mention that though MDA has been widely used as an indicator of oxidative stress, its specificity and sensitivity are still under debate (Grotto et al. 2009).

Excessive exposure to oxidative stress can result in oxidative DNA modifications, and one of the by-products is 8 -OHdG, which is a popular marker of oxidative stress and oxidative-induced DNA damage (Dabrowska \& Wiczkowski 2017). Several studies have measured 8-OHdG levels in blood and urine to understand the role of oxidative DNA damage in disease pathogenesis (Evans et al. 2004). To date, very few studies have reported that elevated 8-OHdG levels in follicular fluid are associated with poor oocyte quality (Tamura et al. 2008, Da Broi et al. 2016, Várnagy et al. 2020). The mean value for follicular 8-OHdG levels in this study was 22.40 , which were much higher than those reported by Tamura et al. (2014)'s value of 5.7-6.6 $\mu \mathrm{g} / \mathrm{L}$ and Várnagy et al. (2020)'s value of $<12$ $\mu \mathrm{g} / \mathrm{L}$ but close to Da Broi et al. (2016)'s value of 17.22-23.19 $\mu \mathrm{g} / \mathrm{L}$. We found that follicular 8-OHdG levels in women with infertility problems (including cases with combined male and female infertility factors) $(21.43 \mu \mathrm{g} / \mathrm{L})$ were not significantly different from those in women without fertility problems $(22.84 \mu \mathrm{g} / \mathrm{L})$ with $P=0.318$. The same results were obtained after cases when the combined male and female infertility factors were excluded. In seminal plasma, the mean 8-OHdG value was high $(175.59 \mu \mathrm{g} / \mathrm{L})$. Researchers have shown that elevated 8-OHdG levels in semen were associated with male infertility (Nakamura et al. 2002, Sakamoto et al. 2008, Cambi et al. 2013, Micillo et al. 2016, Tang et al. 2016, Vatannejad et al. 2017) and poor assisted reproductive technology (ART) outcome (Ahelik et al. 2015). Our 8-OHdG levels were much higher than $1.95 \mu \mathrm{g} / \mathrm{L}$ (Hammadeh et al. 2010); $36.4 \mu \mathrm{g} / \mathrm{L}$ reported by Sakamoto et al. (2008); 7.7 (subfertile) and $7.8 \mu \mathrm{g} / \mathrm{L}$ (infertile) (Nakamura et al. 2002); $0.004 \mu \mathrm{g} / \mathrm{L}$ (Amiri et al. 2011); and 0.08 (normal sperm count) vs $0.1 \mu \mathrm{g} / \mathrm{L}$ (poor motility sperm) (Vatannejad et al. 2017). Our seminal plasma 8-OHdG values represent all men who underwent IVF treatment. In our study, the seminal plasma 8-OHdG levels in men with fertility problems (including cases with both male and female infertility factors) were lower $(167.21 \mu \mathrm{g} / \mathrm{L})$ than those in men without fertility problems $(186.72 \mu \mathrm{g} / \mathrm{L})$, but the difference was of borderline significance $(P=0.059)$. The same results were obtained when cases with combined male and female infertility factors were excluded. Smoking has been consistently identified as a confounder of 8-OHdG (Pilger $\&$ Rudiger 2006), and $23.5 \%$ of the male partners were smokers. However, adjustment for the smoking factor did not alter the findings. An increase in 8-OHdG may not only reflect oxidative DNA damage but also indicate a decline in the DNA repair rate (Tchou \& Grollman 1993, Halliwell 1998). An earlier study (Mecocci et al. 1998) observed that the deficit in DNA repair promotes the accumulation of $8-\mathrm{OHdG}$ in peripheral cells, which could be a better indicator than urine, as urine mainly contains repaired products. However, not many studies have measured cellular 8-OHdG due to sample collection difficulty compared to the urine sample collection.

Catalase is an enzyme that reflects the follicular fluid's antioxidant efficiency, particularly during the early stages of folliculogenesis (Ruder et al. 2008, Gupta et al. 2011). CAT activity in the follicular fluid has been associated with fertilization and cleavage rates but not with pregnancy outcomes in women undergoing ART (Pasqualotto et al. 2009). Only a few studies have measured follicular fluid CAT activity, and they have reported that it is lower in older women (Carbone et al. 2003, Wdowiak 2015) and higher in obese women (Bausenwein et al. 2010). We cannot compare our values to these studies because they were adjusted for protein, except that of Wdowiak (2015). The authors reported CAT levels in follicular fluid of 12.82 $\mathrm{U} / \mathrm{mL}$ in older women of 40-46 years old, significantly lower than in younger ones $(18.91 \mathrm{U} / \mathrm{mL})$. In the present study, CAT levels in the follicular fluid of women who were $\geq 40$ years old $(18.21 \mathrm{U} / \mathrm{mL})$ were not significantly different from those in younger women $(14.55 \mathrm{U} / \mathrm{mL})$. This is probably because older women's sample size was much smaller than young women's sample size (42 vs 528 ). Further, in contrast to previous findings (Bausenwein et al. 2010), we found no significant difference in CAT levels between obese $\left(\mathrm{BMI} \geq 30 \mathrm{~kg} / \mathrm{m}^{2}\right)$ and non-obese women.

Since 1989, CAT activity in the semen has been recognized as an indicator of sperm function (Jeulin et al. 1989). CAT eliminates $\mathrm{H}_{2} \mathrm{O}_{2}$ by converting it to water and oxygen, thus, improving sperm motility (Baker et al. 1996). However, environmental and lifestyle factors, such as smoking, are known to reduce CAT activity and, subsequently, cause a decline in semen quality (Kumar et al. 2014). Unlike the follicular fluid findings, many studies have reported a reduction in the seminal plasma CAT activity among infertile men (Sharma \& Agarwal 1996, Abd-Elmoaty et al. 2010, Agarwal et al. 2012b). In general, mean value for seminal CAT levels in the present study $(10.132 \mathrm{U} / \mathrm{mL})$ was much lower than those reported by Hajizadeh Maleki (2017) in all the four different groups of healthy men undergoing different levels and times of training and values reported by Khosrowbeygi (2007) for healthy vs infertile (22.58 vs $14.4 \mathrm{U} / \mathrm{mL}$ ). However, in ( 
the present study, we did not find significant differences in seminal CAT activities between normozoospermic and infertile men or between smokers and nonsmokers. Further, the CAT levels in follicular fluid and seminal plasma were both low. Thus, insufficient antioxidant levels may not protect against oxidative stress in both follicles and sperm, particularly during IVF treatment, as reported previously (Rakhit et al. 2013).

Elizur (2014) observed that $\mathrm{H}_{2} \mathrm{O}_{2}$ might be a potential marker for ovarian aging-related changes in follicular fluid's metabolic activity. $\mathrm{H}_{2} \mathrm{O}_{2}$ is considered a major contributor to oxidative stress because it oxidizes only a limited number of functional groups of biological molecules and is, therefore, only moderately reactive and permeable through membranes (Fujii \& Tsunoda 2011). However, the findings reported by researchers are conflicting. While Gupta et al. (2011) found high levels of $\mathrm{H}_{2} \mathrm{O}_{2}$ in small bovine follicles that might have reflected an increase in ROS production during the earlier stages of folliculogenesis, Basini et al. (2008) observed reduced $\mathrm{H}_{2} \mathrm{O}_{2}$ levels in swine follicular fluids (which might indicate that oxidative stress does not affect follicle growth). Further, an experimental study found that high exposure to intracellular $\mathrm{H}_{2} \mathrm{O}_{2}$ activates myeloperoxidase and leads to oocyte quality deterioration (Khan et al. 2015). Our study is the first to provide data on the levels of $\mathrm{H}_{2} \mathrm{O}_{2}$ in human follicular fluid. In our study, the mean $\mathrm{H}_{2} \mathrm{O}_{2}$ value was $6.07 \mu \mathrm{g} / \mathrm{L}$, and no significant difference was observed between infertile women and those without fertility problems. A study observed an increase in sperm motility in the presence of low $\mathrm{H}_{2} \mathrm{O}_{2}$ levels, which might, therefore, be a marker of antioxidant activity in sperm cells (Evdokimov et al. 2015). However, increased production of $\mathrm{H}_{2} \mathrm{O}_{2}$ can damage sperm function (Sanocka \& Kurpisz 2004, Du Plessis et al. 2010). Elevated seminal plasma $\mathrm{H}_{2} \mathrm{O}_{2}$ levels have been reported in infertile men with severe inflammation $(21.06 \mu \mathrm{g} / \mathrm{L})$ and those without inflammation $(21.94 \mu \mathrm{g} / \mathrm{L})$ (Kullisaar et al. 2013). Both values were approximately two-fold higher than the mean value $(10.66 \mu \mathrm{g} / \mathrm{L})$ reported in this study. In the present study, although we found no significant difference in seminal $\mathrm{H}_{2} \mathrm{O}_{2}$ levels between normozoospermic and infertile men, other studies have shown that the seminal $\mathrm{H}_{2} \mathrm{O}_{2}$ levels in infertile men are five- to ten-fold higher than those in the control group (Kullisaar et al. 2013, Zandieh et al. 2018).

Follicular fluid represents a vital environment that contains steroid hormones, ROS, proteins, and antioxidants enzymes that are important for follicular development in the ovary (Agarwal et al. 2003, Ambekar et al. 2013, Freitas et al. 2017). Several studies found that higher follicular fluid TAC levels were associated with oocyte competence and successful pregnancy outcomes (Pasqualotto et al. 2004, Ruder et al. 2008, Bedaiwy et al. 2012, Kazemi et al. 2013). The mean follicular fluid TAC value in studied women $(728.14 \mu \mathrm{M})$ was higher than those reported by Singh et al. (2013) for women with endometriosis $(658.32 \mu \mathrm{M})$ but lower than those with tubal infertility $(896.25 \mu \mathrm{M})$. In the present study, we observed significantly higher follicular fluid TAC among infertile women $(785.41 \mu \mathrm{M})$ than the fertile ones $(692.7$ $\mu \mathrm{M})$, but not different from those with other causes of female infertility. Infertile women, particularly those undergoing IVF treatment, tend to take multivitamins and supplements to strengthen their chance of getting pregnant (Ozkaya \& Naziroglu 2010). This might explain the finding in our study population.

We observed no significant differences in seminal plasma TAC levels between normozoospermic (598.18 $\mu \mathrm{M})$ and infertile men $(570.52 \mu \mathrm{M})$. Both values were much lower than those reported for healthy male living in low $(900 \mu \mathrm{M})$ and high $(1200 \mu \mathrm{M})$ polluted areas (Bergamo et al. 2016). However, several studies have found lower TAC levels in the seminal plasma of infertile men (Pasqualotto et al. 2000, Giulini et al. 2009, Khosravi et al. 2014). An investigation established a diagnostic TAC cut-off value of $1947 \mu \mathrm{M}$ in seminal plasma as a marker of oxidative stress among infertile men (Roychoudhury et al. 2016). Only one case in the present study had seminal TAC levels that were above this cut-off. A study found that smoking can lower TAC levels in infertile men's seminal plasma (Saleh et al. 2002). In the present study, smokers had slightly higher seminal TAC levels $(603.59 \mu \mathrm{M})$ than nonsmokers $(533.44 \mu \mathrm{M})$, but the difference was not statistically significant.

\section{DNA damage profile in couples}

A study recommended using human cumulus cells as a screening tool for female reproductive toxicants since they are readily available through IVF procedures, can be maintained using simple culture protocols, and show high potential to differentiate into granulosa cells with high predictability (Hughes et al. 1990). An earlier study by Sinko et al. (2005) detected DNA damage in cumulus cells related to smoking. The authors recommended using the comet assay to evaluate the effect of chemicals on the female reproductive system using cumulus cells because they play an essential role in oocyte maturation, ovulation, and fertilization. Here, we observed a high

This work is licensed under a Creative Commons Attribution-NonCommercial-NoDerivatives 4.0 International License. International License.
aded from Bioscientifica.com at 04/26/2023 12:50:10AM 
degree of DNA damage in the cumulus cells, which might influence oocyte development's competence; however, this association has not been well established in the literature (Raman et al. 2001, Barcena et al. 2015, Tola et al. 2019). DNA damage in granulosa cells taken from women with infertility problems was not statistically different from that in women without infertility problems. We also observed that smoking did not cause DNA damage in the granulosa cells.

The comet assay has been recognized as a highly sensitive tool to assess sperm DNA damage, particularly in men with infertility (Schulte et al. 2010, Simon \& Carrell 2013) and as a potential marker of the IVF/ICSI success (Nicopoullos et al. 2019). In the current study, the sperm cells showed evidence of DNA damage; however, unlike other studies, we found no differences in both parameters between normozoospermic and infertile men (Aydos et al. 2015, Ramzan et al. 2015, Fernandez-Encinas et al. 2016). Researchers observed that sperm dsDNA exhibits an increase in breaks with age (Singh et al. 2003, Das et al. 2013). However, no correlation was found in the present study between age and TM. Smoking is another factor that might induce DNA damage (Linschooten et al. 2011, Antoniassi et al. 2016), but in this study, we only noted that the DNA damage was significantly higher in male partners who smoked water pipes than nonsmokers $(P=0.023)$ but not in men who smoked cigarettes. Men who smoked both cigarettes and water pipes showed a significant increase in sperm cells DNA damage than nonsmokers $(P=0.032)$. A recent study showed a difference in DNA damage's susceptibility between the two sex chromosome (X and Y) spermatozoa (Shi et al. 2019).

\section{Associations between oxidative stress/DNA damage biomarkers}

In this study, biochemical markers, whether measured in women or their male partners, were inter-correlated. The higher the MDA levels in follicular fluid, the more was the DNA damage in the granulosa cells, as indicated by the TM values. These findings imply that follicles are more prone to oxidative stress and DNA damage. Granulosa cells play an essential role in protecting oocytes against oxidative stress-induced apoptosis by stimulating oocyte glutathione activity (Tatemoto et al. 2000); moreover, oocyte competence is associated with the DNA status of cumulus cells (Raman et al. 2001). Here, the follicular fluid 8-OHdG levels were inversely associated with DNA damage markers, but these two parameters were positively correlated in seminal plasma. This finding indicates that the imbalance between ROS production and antioxidant activity in follicular fluid and seminal plasma might differ, as corroborated by a previous study (Rahal et al. 2014). This could be partly explained by the positive association observed between DNA damage markers and follicular fluid TAC levels, which was not observed in seminal plasma; instead, the DNA damage markers were associated with $\mathrm{H}_{2} \mathrm{O}_{2}$ in seminal plasma. Sperm DNA damage is primarily a result of oxidative stress, which can be adequately managed with antioxidant therapy (Lewis et al. 2013, Agarwal et al. 2014).

The seminal plasma MDA and 8-OHdG levels were significantly correlated; this may indicate the effect of lipid peroxidation on DNA damage. A similar finding was reported by (Hosen et al. 2015), but (Nakamura et al. 2002) found contradictory findings. MDA can react with deoxyguanosine and deoxyadenosine in DNA to form adducts (Marnett 1999); this results in the formation of 8-OHdG, which is proportional to the lipid peroxidation level as reflected by MDA (Park \& Floyd 1992). In follicular fluid, MDA was unexpectedly negatively associated with $\mathrm{H}_{2} \mathrm{O}_{2}$ and positively associated with TAC. As discussed earlier, both MDA and $\mathrm{H}_{2} \mathrm{O}_{2}$ are oxidative stress markers, while TAC represents the antioxidant defense system. Lipid peroxidation damage that is caused by ROS generated from $\mathrm{H}_{2} \mathrm{O}_{2}$ may depend on an equilibrium mechanism between the production and scavenging of ROS (Sharma et al. 2012). In seminal plasma, high ROS levels reflected by $\mathrm{H}_{2} \mathrm{O}_{2}$ were associated with an increase in lipid peroxidation and oxidative DNA damage, which are represented by MDA and 8-OHdG, respectively. Similar findings have been reported by other researchers (Colagar et al. 2009, Gharagozloo \& Aitken 2011).

In follicular fluid, the higher the oxidative DNA damage indicated by $8-\mathrm{OHdG}$, the higher was the CAT activity observed. This confirms the antioxidant role of CAT in scavenging ROS, as discussed earlier. The high CAT activity in follicular fluid might explain the inverse association between $\mathrm{H}_{2} \mathrm{O}_{2}$ and 8-OHdG observed in this study. The positive correlation between CAT and TAC (Table 3) indicates that both scavenge ROSs generated from $\mathrm{H}_{2} \mathrm{O}_{2}$ in follicular fluid. This is probably because there is more demand for antioxidants in the follicular fluid of poorly developed oocytes (Singh et al. 2013, Revelli et al. 2017). Again, we observed that the more ROS generated in seminal plasma, the higher was the oxidative DNA damage. Unlike the observations in follicular fluid, in seminal plasma, CAT seems to have no role in reducing the ROS effect; this might reflect the antioxidant defense

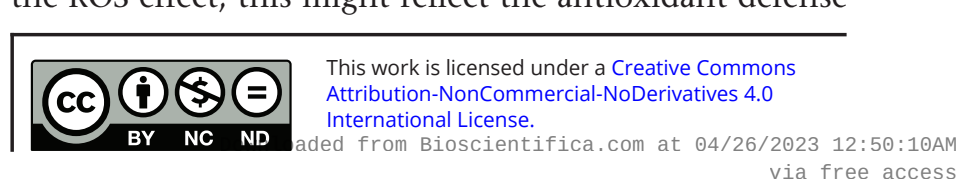


system's inadequacy in seminal plasma. Such an imbalance between ROS production and antioxidant activity in the seminal plasma may impact spermatozoa and its overall fertilizing capacity (Agarwal et al. 2014).

The oxidative stress status in follicular fluid and seminal plasma may vary because they differ with regard to their extent to environmental exposure, ROS generation, and antioxidant capacity (Agarwal et al. 2003). Furthermore, oxidative stress markers are altered by smoking, diet, disease, genetic predispositions, and environmental factors (Kumar et al. 2014, Harlev et al. 2015, Bisht et al. 2017). However, these effects will not be discussed here because this is beyond the scope of this study.

Finally, we observed that CAT activity in follicular fluid increased significantly with urinary COT levels in women; this probably had a protective effect on cells from the damaging effects of ROS produced by smoking (Pasqualotto et al. 2008, Elshal et al. 2009). However, the seminal plasma's CAT activity was associated with male partners' urinary COT levels but with marginal significance. Our results showed that though none of the women in this study were smokers, COT was detected in $49.3 \%$ of follicular fluid samples. This was consequently associated with the induction of oxidative stress, as demonstrated by its association with $\mathrm{H}_{2} \mathrm{O}_{2}$ and TM. It has been reported that COT readily crosses the blood/follicle barrier, so this might explain our findings in follicular fluid (Paszkowski 1998). The COT present in follicular fluid might have impacted the quality of oocytes and their maturation. A study showed that COT interacts directly with and incorporates into the follicle cells and the developing oocyte, which has detrimental consequences after conception (Zenzes et al. 1997). Surprisingly, despite the high levels of the seminal plasma COT levels, it was only significantly associated with $\mathrm{H}_{2} \mathrm{O}_{2}$, which may negatively play a role in male fertility, as reported previously (Harlev et al. 2015).

\section{Associations between biomarkers of oxidative stress/ DNA damage and reproductive hormones}

In the present study, we observed that higher levels of LH in women were associated with increased follicular fluid ROS generation, as represented by 8-OHdG. Twenty-nine women (4.9\%) had LH above the upper KFSH\&RC reference limit of $12.6 \mathrm{IU} / \mathrm{L}$. Researchers have warned that the early surges in LH usually prevent the effective induction of multiple follicular maturation patterns (Al-Inany et al. 2016). On the other hand, lower LH has been associated with greater DNA damage in cumulus cells, as indicated by the TM level. LH induces ROS generation to modulate oocyte maturation, ovarian steroidogenesis, corpus luteal function, and luteolysis, which are generally maintained by the well-balanced antioxidant system (Kala et al. 2017). In this study, 138 (23.4\%) women had LH levels that were lower than the KFSH\&RC reference limit of $2.4 \mathrm{U} / \mathrm{L}$, which is indicative of poor reproductive performance (Peñarrubia et al. 2003). This might have impaired the antioxidant system and led to ROS overproduction and subsequent DNA damage.

The higher ROS generation, in the form of $\mathrm{H}_{2} \mathrm{O}_{2}$, was associated with a reduction in serum TSH levels in women. Low TSH levels are indicative of hyperthyroidism (Obuobie \& Jones 2003). Only five women had TSH levels lower than the reference limit of $0.27 \mathrm{mU} / \mathrm{L}$, which indicates overactive thyroid function, and 73 had TSH levels above the upper limit of $4.2 \mathrm{mU} / \mathrm{L}$, which suggests hypothyroidism. Both hyper- and hypothyroidism have been linked to female infertility (American Society for Reproductive Medicine 2015, Mintziori et al. 2016). Additionally, the association between oxidative stress and excess or low TSH levels is well documented (Mancini et al. 2016). It has been reported that hyperthyroidism increases oxidative stress, whereas hypothyroidism decreases ROS production and antioxidant activity (Villanueva et al. 2013).

The DNA damage marker TM was inversely associated with higher $\mathrm{E}_{2}$ levels in women. Low $\mathrm{E}_{2}$ reflects poor ovarian response after using standard stimulation IVF protocols (Tarlatzis et al. 2003, Jirge 2016). A study by Kalemba-Drozdz (2015) found that $E_{2}$ is a naturally occurring antioxidant that may play a protective role during pregnancy. The authors found that $\mathrm{E}_{2}$ was negatively associated with oxidative DNA damage. In this study, $32.4 \%$ of women had lower than normal $\mathrm{E}_{2}$ levels (lower than the KFSH\&RC reference limit of $46 \mathrm{pmol} / \mathrm{L}$ ). Based on these findings, it can be assumed that the lower the $\mathrm{E}_{2}$ level, the higher is the DNA damage in cumulus cells.

The higher the seminal plasma MDA levels in male partners, the lesser were the serum FSH levels. FSH plays an essential role in maintaining male reproductive functions (Ulloa-Aguirre \& Lira-Albarran 2016). Further, increased ROS generation in seminal plasma potentially affects male infertility (Sabeti et al. 2016). Here, 9.3\% of the men had FSH levels lower than the KFSH\&RC reference limit of $1.5 \mathrm{IU} / \mathrm{l}$. ROS generated by alcohol, smoking, or environmental factors might affect FSH synthesis (Oremosu \& Akang 2015, Aprioku \& Ugwu 2016, Zubair 
et al. 2017). Research has shown that ROS affects FSH's secretion via its effect on the gonadotropin-releasing hormone (Terasaka et al. 2017). This mechanism could not be corroborated in the present study.

Increased levels of $8-\mathrm{OHdG}$ and MDA in seminal plasma have been associated with male infertility (Huang et al. 2018). We observed that higher seminal plasma levels of MDA and 8-OHdG were associated with elevated serum $\mathrm{T}$ levels in the male partners. Although oxidative stress can result in Leydig cell dysfunction or apoptosis and diminished $\mathrm{T}$ production (Dabaja et al. 2013), experimental studies have reported that $\mathrm{T}$ can induce oxidative stress on account of its pro-oxidant properties (Alonso-Alvarez et al. 2007) and act as an antioxidant by protecting sperm and other testicular cells from ROS damage (Darbandi et al. 2018). As $\mathrm{T}$ plays a vital role in the initiation and maintenance of spermatogenesis (Gudeloglu \& Parekattil 2013), abnormal T levels may directly impact male fertility.

We want to acknowledge a major limitation of our study. As reported previously, the levels of reproductive hormones may vary within an individual over time, and not all patients were assessed on their initial visit to the clinic (Brambilla et al. 2009).

\section{Impact of oxidative stress and DNA damage on IVF outcomes}

The present study showed that high CAT levels in follicular fluid might reduce the risk of poor fertilization rate $(\leq 50 \%)$ and unsuccessful live birth by 48 and $41 \%$, respectively. Pasqualotto et al. (2009) observed a correlation between follicular fluid CAT levels and fertilization rate, but not with pregnancy rate. Here, after the multivariate log-binomial regression models were adjusted for the hormonal factors $\mathrm{FSH}, \mathrm{LH}$, and $\mathrm{E}_{2}$, only the association between elevated follicular fluid CAT levels and low risk of poor fertilization remained significant. However, when the models controlled for hormonal factors TSH and Prl, high CAT levels in follicular fluid were still associated with a reduced risk of both poor fertilization rate $(\leq 50 \%)$ and unsuccessful live birth. In contrast to the findings of Oyawoye et al. (2003) and Varnagy et al. (2018), we also observed an association between high levels of follicular TAC and a low probability of poor fertilization rate.

It has been suggested that sex hormones have a potential role in regulating the synthesis and activity of antioxidants (Mancini et al. 2010) or in regulating antioxidant gene expression (Bellanti et al. 2013).
Although several studies have investigated the impact of oxidative stress in follicular fluid on IVF outcomes, it is hard to draw a definite conclusion because of conflicting results resulting from the use of various markers and IVF outcomes such as live birth, oocyte quality, fertilization rate, and pregnancy rate (Askoxylaki et al. 2013). For example, some studies have reported associations between high follicular fluid levels of TAC and pregnancy and increase in follicle size (Gupta et al. 2011, Bedaiwy et al. 2012), between lipid peroxidation and pregnancy rate (Pasqualotto et al. 2009), between 8-OHdG and oocyte quality (Tamura et al. 2008), between superoxide dismutase and the quality of embryos on the second day of development (Wdowiak 2015), and between MDA and oocyte retrieval (Thaker et al. 2020). From all these findings, it seems that ROS affects embryo development at different stages. Our results indicate that the CAT and TAC activities observed in the follicular fluid samples probably played a role in neutralizing ROS production. Therefore, as reported in a previous study, CAT and TAC could be potential markers of mature follicles, leading to the growth of high-quality oocytes (Gupta et al. 2011).

\section{Study limitations and strengths}

The study has several limitations to consider when interpreting the results. First, the studied population was recruited from the IVF clinic, thereby restricting the generalization of our findings to the general population. Secondly, the possibility of uncontrolled potential confounding variables that might be related to the oxidative stress and/or the outcomes (IVF endpoints). Thirdly, self-reported variables might have introduced a bias in the results. Fourthly, the use of ELISA assays to measure oxidative stress biomarkers that might be less accurate than mass spectrometry techniques. Fifthly, no internal quality controls were provided by the ELISA manufacturers to evaluate the intra-and -inter-assay precision. Sixthly, given ROS's highly reactive nature, the stability of $\mathrm{H}_{2} \mathrm{O}_{2}$ might be affected after a lengthy storage period. However, the samples were processed on time that hopefully make the change constant. Despite these limitations, our study has many strengths: (1) large sample size, (2) prospective design, (3) measurement of several oxidative stress biomarkers in couples, (4) being conducted in an IVF setting, giving us access to various endpoints, and (5) numerous confounding variables concerning demographic, socioeconomic, lifestyle, and health collected from each couple. 


\section{Conclusions}

The present study results show that oxidative stress and DNA damage biomarkers in couples undergoing IVF were associated with several reproductive hormones and smoking status. The findings indicate ROS's disruptive effect on hormones and the consequent adverse effects on male and female reproductive functions. In this regard, our results demonstrated that elevated levels of CAT in follicular fluid reduced the risk of poor fertilization rate $(\geq 50 \%)$ and unsuccessful live birth. Further, higher levels of follicular fluid TAC were found to reduce the risk of poor fertilization rate but only after the data were adjusted for hormonal factors. This indicates the potential role of these hormones in regulating antioxidant behavior. In conclusion, higher antioxidant activity in follicular fluid might have a positive impact on specific IVF outcomes. Additionally, biomarkers of oxidative stress and DNA damage might have potential applications in evaluating IVF patients' clinical characteristics.

\section{Declaration of interest}

The authors declare that there is no conflict of interest that could be perceived as prejudicing the impartiality of the research reported.

\section{Funding}

This work was supported by King Abdulaziz City for Science and Technology for funding this research (grant number ARP-34-27, 2013); and King Faisal Specialist Hospital and Research Centre (RAC\#2132024, 2013).

\section{Data availability}

The data that has been used is confidential.

\section{Author contribution statement}

Iman Al-Saleh was involved in designing/writingpProject management and supervision. Coskun Serdar was involved in IVF procedures/sample collection and parameters. Reem Al-Rouqi, Tahreer Al-Rajoudi, Chafica Eltabache, and Mai Abduljabbar were involved in Methodology/validation. Saad Al-Hassan was involved in clinical assessment and selection of IVF couples.

\section{References}

Abd-Elmoaty MA, Saleh R, Sharma R \& Agarwal A 2010 Increased levels of oxidants and reduced antioxidants in semen of infertile men with varicocele. Fertility and Sterility 94 1531-1534. (https://doi. org/10.1016/j.fertnstert.2009.12.039)
Agarwal A \& Allamaneni SS 2011 Free radicals and male reproduction. Journal of the Indian Medical Association 109 184-187.

Agarwal A \& Sekhon LH 2011 Oxidative stress and antioxidants for idiopathic oligoasthenoteratospermia: is it justified? Indian Journal of Urology 27 74-85. (https://doi.org/10.4103/0970-1591.78437)

Agarwal A, Saleh RA \& Bedaiwy MA 2003 Role of reactive oxygen species in the pathophysiology of human reproduction. Fertility and Sterility 79 829-843. (https://doi.org/10.1016/s0015-0282(02)04948-8)

Agarwal A, Aponte-Mellado A, Premkumar BJ, Shaman A \& Gupta S $2012 a$ The effects of oxidative stress on female reproduction: a review. Reproductive Biology and Endocrinology 10 49-49. (https://doi.org/10.1186/1477-7827-10-49)

Agarwal A, Hamada A \& Esteves SC $2012 b$ Insight into oxidative stress in varicocele-associated male infertility: part 1. Nature Reviews: Urology 9 678-690. (https://doi.org/10.1038/ nrurol.2012.197)

Agarwal A, Virk G, Ong C \& Du Plessis SS 2014 Effect of oxidative stress on male reproduction. World Journal of Men's Health 32 1-17. (https://doi.org/10.5534/wjmh.2014.32.1.1)

Agarwal A, Roychoudhury S, Bjugstad KB \& Cho CL 2016 Oxidation-reduction potential of semen: what is its role in the treatment of male infertility? Therapeutic Advances in Urology 8 302-318. (https://doi.org/10.1177/1756287216652779)

Ahelik A, Mandar R, Korrovits P, Karits P, Talving E, Rosenstein K, Jaagura M, Salumets A \& Kullisaar T 2015 Systemic oxidative stress could predict assisted reproductive technique outcome. Journal of Assisted Reproduction and Genetics 32 699-704.

Al-Inany HG, Youssef MA, Ayeleke RO, Brown J, Lam WS \& Broekmans FJ 2016 Gonadotrophin-releasing hormone antagonists for assisted reproductive technology. Cochrane Database of Systematic Reviews 4 CD001750. (https://doi.org/10.1002/14651858.CD001750. pub4)

Alonso-Alvarez C, Bertrand S, Faivre B, Chastel o \& Sorci G 2007 Testosterone and oxidative stress: the oxidation handicap hypothesis. Proceedings: Biological Sciences 274 819-825. (https://doi. org/10.1098/rspb.2006.3764)

Al-Saleh I, Billedo G \& Shinwari N 2007 Serum malonyldialdehyde levels in Saudi population and its relationship to a number of factors such as age, gender, antioxidant levels and health status. Trace Elements and Electrolytes 24 103-111. (https://doi.org/10.5414/ TEP24103)

Ambekar AS, Nirujogi RS, Srikanth SM, Chavan S, Kelkar DS, Hinduja I, Zaveri K, Prasad TS, Harsha HC, Pandey A, et al. 2013 Proteomic analysis of human follicular fluid: a new perspective towards understanding folliculogenesis. Journal of Proteomics $\mathbf{8 7}$ 68-77. (https://doi.org/10.1016/j.jprot.2013.05.017)

American Society for Reproductive Medicine 2015 Subclinical hypothyroidism in the infertile female population: a guideline. Fertility and Sterility 104 545-553. (https://doi.org/10.1016/j. fertnstert.2015.05.028)

Amiri I, Karimi J, Piri H, Goodarzi MT, Tavilani H, Khodadadi I \& Ghorbani M 2011 Association between nitric oxide and 8-hydroxydeoxyguanosine levels in semen of diabetic men. Systems Biology in Reproductive Medicine 57 292-295. (https://doi.org/10.3109/ 19396368.2011.621508)

Antoniassi MP, Intasqui P, Camargo M, Zylbersztejn DS, Carvalho VM, Cardozo KH \& Bertolla RP 2016 Analysis of the functional aspects and seminal plasma proteomic profile of sperm from smokers. BJU International 118 814-822. (https://doi. org/10.1111/bju.13539)

Aprioku JS \& Ugwu TC 2016 Tobacco smoke exposure induces irreversible alteration of testicular function in prepubertal rats. Journal of Basic and Clinical Physiology and Pharmacology 27 577-584. (https://doi.org/10.1515/jbcpp-2015-0153)

Artimani T, Karimi J, Mehdizadeh M, Yavangi M, Khanlarzadeh E, Ghorbani M, Asadi S \& Kheiripour N

This work is licensed under a Creative Commons Attribution-NonCommercial-NoDerivatives 4.0 International License. ded from Bioscientifica.com at 04/26/2023 12:50:10AM 
2018 Evaluation of pro-oxidant-antioxidant balance (PAB) and its association with inflammatory cytokines in polycystic ovary syndrome (PCOS). Gynecological Endocrinology 34148-152. (https:// doi.org/10.1080/09513590.2017.1371691)

Asadi N, Bahmani M, Kheradmand A \& Rafieian-Kopaei M 2017 The impact of oxidative stress on testicular function and the role of antioxidants in improving it: a review. Journal of Clinical and Diagnostic Research 11 IE01-IE05. (https://doi.org/10.7860/ JCDR/2017/23927.9886)

Askoxylaki M, Siristatidis C, Chrelias C, Vogiatzi P, Creatsa M, Salamalekis G, Vrantza T, Vrachnis N \& Kassanos D 2013 Reactive oxygen species in the follicular fluid of subfertile women undergoing in vitro fertilization: a short narrative review. Journal of Endocrinological Investigation 36 1117-1120. (https://doi. org/10.3275/9097)

Atig F, Kerkeni A, Saad A \& Ajina M 2017 Effects of reduced seminal enzymatic antioxidants on sperm DNA fragmentation and semen quality of Tunisian infertile men. Journal of Assisted Reproduction and Genetics 34 373-381. (https://doi.org/10.1007/ s10815-013-9936-x)

Avila J, Gonzalez-Fernandez R, Rotoli D, Hernandez J \& Palumbo A 2016 Oxidative stress in granulosa-lutein cells from in vitro fertilization patients. Reproductive Sciences 23 1656-1661. (https://doi.org/10.1177/1933719116674077)

Aydos OS, Yukselten Y, Kaplan F, Sunguroglu A \& Aydos K 2015 Analysis of the correlation between sperm DNA integrity and conventional semen parameters in infertile men. Turkish Journal of Urology 41 191-197. (https://doi.org/10.5152/tud.2015.98475)

Baker HW, Brindle J, Irvine DS \& Aitken RJ 1996 Protective effect of antioxidants on the impairment of sperm motility by activated polymorphonuclear leukocytes. Fertility and Sterility 65 411-419. (https://doi.org/10.1016/s0015-0282(16)58109-6)

Balhara YP, Jain R, Sundar AS \& Sagar R 2012 Use of cotinine urinalysis to verify self-reported tobacco use among male psychiatric out-patients. Lung India 29 217-220. (https://doi.org/10.4103/09702113.99102)

Barcena P, López-Fernández C, García-Ochoa C, Obradors A, Vernaeve V, Gosálvez J \& Vassena R 2015 Detection of DNA damage in cumulus cells using a chromatin dispersion assay. Systems Biology in Reproductive Medicine 61 277-285. (https://doi.org/10.3109/ 19396368.2015.1063739)

Barros AJD \& Hirakata VN 2003 Alternatives for logistic regression in cross-sectional studies: an empirical comparison of models that directly estimate the prevalence ratio. BMC Medical Research Methodology 3 21. (https://doi.org/10.1186/1471-2288-3-21)

Basini G, Simona B, Santini SE \& Grasselli F 2008 Reactive oxygen species and anti-oxidant defences in swine follicular fluids. Reproduction, Fertility, and Development 20 269-274. (https://doi. org/10.1071/rd07147)

Bausenwein J, Serke H, Eberle K, Hirrlinger J, Jogschies P, Hmeidan FA, Blumenauer V \& Spanel-Borowski K 2010 Elevated levels of oxidized low-density lipoprotein and of catalase activity in follicular fluid of obese women. Molecular Human Reproduction 16 117-124. (https://doi.org/10.1093/molehr/gap078)

Bedaiwy MA, Elnashar SA, Goldberg JM, Sharma R, Mascha EJ, Arrigain S, Agarwal A \& Falcone T 2012 Effect of follicular fluid oxidative stress parameters on intracytoplasmic sperm injection outcome. Gynecological Endocrinology 28 51-55. (https://doi.org/10.31 09/09513590.2011.579652)

Bellanti F, Matteo M, Rollo T, De Rosario F, Greco P, Vendemiale G \& Serviddio G 2013 Sex hormones modulate circulating antioxidant enzymes: impact of estrogen therapy. Redox Biology 1 340-346. (https://doi.org/10.1016/j.redox.2013.05.003)

Benedict MD, Missmer SA, Vahratian A, Berry KF, Vitonis AF, Cramer DW \& Meeker JD 2011 Secondhand tobacco smoke exposure is associated with increased risk of failed implantation and reduced IVF success. Human Reproduction 26 2525-2531. (https://doi. org/10.1093/humrep/der226)

Bergamo P, Volpe MG, Lorenzetti S, Mantovani A, Notari T, Cocca E, Cerullo S, Di Stasio M, Cerino P \& Montano L 2016 Human semen as an early, sensitive biomarker of highly polluted living environment in healthy men: a pilot biomonitoring study on trace elements in blood and semen and their relationship with sperm quality and RedOx status. Reproductive Toxicology 66 1-9. (https://doi. org/10.1016/j.reprotox.2016.07.018)

Bisht S, Faiq M, Tolahunase M \& Dada R 2017 Oxidative stress and male infertility. Nature Reviews: Urology 14 470-485. (https://doi. org/10.1038/nrurol.2017.69)

Black CN, Bot M, Scheffer PG \& Penninx BW 2016 Sociodemographic and lifestyle determinants of plasma oxidative stress markers 8-OHdG and F2-isoprostanes and associations with metabolic syndrome. Oxidative Medicine and Cellular Longevity 2016 7530820. (https://doi.org/10.1155/2016/7530820)

Brambilla DJ, Matsumoto AM, Araujo AB \& Mckinlay JB 2009 The effect of diurnal variation on clinical measurement of serum testosterone and other sex hormone levels in men. Journal of Clinical Endocrinology and Metabolism 94 907-913. (https://doi.org/10.1210/ jc.2008-1902)

Cambi M, Tamburrino L, Marchiani S, Olivito B, Azzari C, Forti G, Baldi E \& Muratori M 2013 Development of a specific method to evaluate 8-hydroxy, 2-deoxyguanosine in sperm nuclei: relationship with semen quality in a cohort of 94 subjects. Reproduction 145 227-235. (https://doi.org/10.1530/REP-12-0404)

Carbone MC, Tatone C, Delle Monache S, Marci R, Caserta D, Colonna R \& Amicarelli F 2003 Antioxidant enzymatic defences in human follicular fluid: characterization and age-dependent changes. Molecular Human Reproduction 9 639-643. (https://doi. org/10.1093/molehr/gag090)

Chari MG \& Colagar AH 2011 Seminal plasma lipid peroxidation, total antioxidant capacity, and cigarette smoking in asthenoteratospermic men. Journal of Men's Health 8 43-49. (https://doi.org/10.1016/j. jomh.2010.09.230)

Colagar AH, Pouramir M, Marzony ET \& Jorsaraei SGA 2009 Relationship between seminal malondialdehyde levels and sperm quality in fertile and infertile men. Brazilian Archives of Biology and Technology 52 1387-1392. (https://doi.org/10.1590/S151689132009000600010)

Collins AR 2015 The comet assay: a heavenly method! Mutagenesis 30 1-4. (https://doi.org/10.1093/mutage/geu079)

Collodel G, Moretti E, Micheli L, Menchiari A, Moltoni L \& Cerretani D 2015 Semen characteristics and malondialdehyde levels in men with different reproductive problems. Andrology 3 280-286. (https://doi.org/10.1111/andr.297)

Da Broi MG, De Albuquerque Fo, De Andrade AZ, Cardoso RL, Jordao Junior AA \& Navarro PA 2016 Increased concentration of 8-hydroxy-2'-deoxyguanosine in follicular fluid of infertile women with endometriosis. Cell and Tissue Research 366 231-242. (https:// doi.org/10.1007/s00441-016-2428-4)

Da Silva J 2016 DNA damage induced by occupational and environmental exposure to miscellaneous chemicals. Mutation Research 770 170-182. (https://doi.org/10.1016/j. mrrev.2016.02.002)

Dabaja A, Wosnitzer M \& Goldstein M 2013 Varicocele and hypogonadism. Current Urology Reports 14 309-314. (https://doi. org/10.1007/s11934-013-0339-4)

Dabrowska N \& Wiczkowski A 2017 Analytics of oxidative stress markers in the early diagnosis of oxygen DNA damage. Advances in Clinical and Experimental Medicine 26 155-166. (https://doi. org/10.17219/acem/43272)

Darbandi M, Darbandi S, Agarwal A, Sengupta P, Durairajanayagam D, Henkel R \& Sadeghi MR 2018 Reactive oxygen species and male reproductive hormones. Reproductive Biology

This work is licensed under a Creative Commons Attribution-NonCommercial-NoDerivatives 4.0 International License. ded from Bioscientifica.com at 04/26/2023 12:50:10AM 
and Endocrinology 16 87-87. (https://doi.org/10.1186/s12958-0180406-2)

Das M, Al-Hathal N, San-Gabriel M, Phillips S, Kadoch IJ, Bissonnette F, Holzer H \& Zini A 2013 High prevalence of isolated sperm DNA damage in infertile men with advanced paternal age. Journal of Assisted Reproduction and Genetics 30 843-848. (https:// doi.org/10.1007/s10815-013-0015-0)

Dattilo M, D'Amato G, Caroppo E \& Ménézo Y 2016 Improvement of gamete quality by stimulating and feeding the endogenous antioxidant system: mechanisms, clinical results, insights on geneenvironment interactions and the role of diet. Journal of Assisted Reproduction and Genetics 33 1633-1648. (https://doi.org/10.1007/ s10815-016-0767-4)

De Lima CB, Cordeiro FB, Camargo M, Zylbersztejn DS, Cedenho AP, Bertolla RP \& Lo Turco EG 2017 Follicular fluid lipid peroxidation levels in women with endometriosis during controlled ovarian hyperstimulation. Human Fertility 20 48-54. (https://doi.org/10.1080/14647273.2016.1246753)

Devine PJ, Perreault SD \& Luderer U 2012 Roles of reactive oxygen species and antioxidants in ovarian toxicity. Biology of Reproduction 86 27. (https://doi.org/10.1095/biolreprod.111.095224)

Du Plessis SS, Mcallister DA, Luu A, Savia J, Agarwal A \& Lampiao F 2010 Effects of H2O2 exposure on human sperm motility parameters, reactive oxygen species levels and nitric oxide levels. Andrologia 42 206-210. (https://doi.org/10.1111/j.14390272.2009.00980.x)

Einaudi L, Courbiere B, Tassistro V, Prevot C, Sari-Minodier I, Orsiere T \& Perrin J 2014 In vivo exposure to benzo(a)pyrene induces significant DNA damage in mouse oocytes and cumulus cells. Human Reproduction 29 548-554. (https://doi.org/10.1093/ humrep/det439)

Elizur SE, Lebovitz O,Orvieto R,Dor J\& Zan-Bar T 2014 Reactive oxygen species in follicular fluid may serve as biochemical markers to determine ovarian aging and follicular metabolic age. Gynecological Endocrinology 30 705-707. (https://doi.org/10.3109/09513590.2014. 924100)

Elshal MF, El-Sayed IH, Elsaied MA, El-Masry SA \& Kumosani TA 2009 Sperm head defects and disturbances in spermatozoal chromatin and DNA integrities in idiopathic infertile subjects: association with cigarette smoking. Clinical Biochemistry 42 589-594. (https://doi.org/10.1016/j.clinbiochem.2008.11.012)

Evans MD, Dizdaroglu M \& Cooke MS 2004 Oxidative DNA damage and disease: induction, repair and significance. Mutation Research $\mathbf{5 6 7}$ 1-61. (https://doi.org/10.1016/j.mrrev.2003.11.001)

Evdokimov VV, Barinova KV, Turovetskii VB, Muronetz VI \& Schmalhausen EV 2015 Low concentrations of hydrogen peroxide activate the antioxidant defense system in human sperm cells. Biochemistry: Biokhimiia 80 1178-1185. (https://doi.org/10.1134/ S0006297915090084)

Fatemi F, Mohammadzadeh A, Sadeghi MR, Akhondi MM, Mohammadmoradi S, Kamali K, Lackpour N, Jouhari S, Zafadoust S, Mokhtar S, et al. 2017 Role of vitamin E and D3 supplementation in intra-cytoplasmic sperm injection outcomes of women with polycystic ovarian syndrome: a double blinded randomized placebo-controlled trial. Clinical Nutrition ESPEN 18 23-30. (https://doi.org/10.1016/j.clnesp.2017.01.002)

Fernandez-Encinas A, Garcia-Peiro A, Ribas-Maynou J, Abad C, Amengual MJ, Navarro J \& Benet J 2016 Characterization of nuclease activity in human seminal plasma and its relationship to semen parameters, sperm DNA fragmentation and male infertility. Journal of Urology 195 213-219. (https://doi.org/10.1016/j. juro.2015.07.089)

Freinbichler W, Colivicchi MA, Stefanini C, Bianchi L, Ballini C, Misini B, Weinberger P, Linert W, Vareslija D, Tipton KF, et al. 2011 Highly reactive oxygen species: detection, formation, and possible functions. Cellular and Molecular Life
Sciences 68 2067-2079. (https://doi.org/10.1007/s00018-0110682-x)

Freitas C, Neto AC, Matos L, Silva E, Ribeiro Â, Silva-Carvalho JL \& Almeida H 2017 Follicular fluid redox involvement for ovarian follicle growth. Journal of Ovarian Research 10 44. (https://doi. org/10.1186/s13048-017-0342-3)

Fuentes A, Muñoz A, Barnhart K, Argüello B, Díaz M \& Pommer R 2010 Recent cigarette smoking and assisted reproductive technologies outcome. Fertility and Sterility 93 89-95. (https://doi. org/10.1016/j.fertnstert.2008.09.073)

Fujii J \& Tsunoda S 2011 Redox regulation of fertilisation and the spermatogenic process. Asian Journal of Andrology 13 420-423. (https://doi.org/10.1038/aja.2011.10)

Gandhi J, Hernandez RJ, Chen A, Smith NL, Sheynkin YR, Joshi G \& Khan SA 2017 Impaired hypothalamic-pituitarytesticular axis activity, spermatogenesis, and sperm function promote infertility in males with lead poisoning. Zygote 25 103-110. (https:// doi.org/10.1017/S0967199417000028)

Gharagozloo P \& Aitken RJ 2011 The role of sperm oxidative stress in male infertility and the significance of oral antioxidant therapy. Human Reproduction 26 1628-1640. (https://doi.org/10.1093/ humrep/der132)

Giulini S, Sblendorio V, Xella S, La Marca A, Palmieri B \& Volpe A 2009 Seminal plasma total antioxidant capacity and semen parameters in patients with varicocele. Reproductive Biomedicine Online 18 617-621. (https://doi.org/10.1016/s1472-6483(10)60004-1)

Greco F, Perrin J, Auffan M, Tassistro V, Orsiere T \& Courbiere B 2015 A new approach for the oocyte genotoxicity assay: adaptation of comet assay on mouse cumulus-oocyte complexes. Laboratory Animals 49 251-254. (https://doi.org/10.1177/0023677214567136)

Grotto D, Maria LS, Valentini J, Paniz C, Schmitt G, Garcia SC, Pomblum VJ, Rocha JBT \& Farina M 2009 Importance of the lipid peroxidation biomarkers and methodological aspects FOR malondialdehyde quantification. Química Nova 32 169-174. (https:// doi.org/10.1590/S0100-40422009000100032)

Gudeloglu A \& Parekattil SJ 2013 Update in the evaluation of the azoospermic male. Clinics 68 (Supplement 1) 27-34. (https://doi. org/10.6061/clinics/2013(sup01)04)

Guerriero G, Trocchia S, Abdel-Gawad FK \& Ciarcia G 2014 Roles of reactive oxygen species in the spermatogenesis regulation. Frontiers in Endocrinology 5 56. (https://doi.org/10.3389/fendo.2014.00056)

Gunasekarana V, Raj GV \& Chand P 2015 A comprehensive review on clinical applications of comet assay. Journal of Clinical and Diagnostic Research 9 GE01-GE05. (https://doi.org/10.7860/ JCDR/2015/12062.5622), Ge01-05.

Gupta S, Choi A, Yu HY, Czerniak SM, Holick EA, Paolella LJ, Agarwal A \& Combelles CM 2011 Fluctuations in total antioxidant capacity, catalase activity and hydrogen peroxide levels of follicular fluid during bovine folliculogenesis. Reproduction, Fertility, and Development 23 673-680. (https://doi.org/10.1071/RD10270)

Hajizadeh Maleki B, Tartibian B\& Chehrazi M 2017 The effects of three different exercise modalities on markers of male reproduction in healthy subjects: a randomized controlled trial. Reproduction 153 157-174. (https://doi.org/10.1530/REP-16-0318)

Halliwell B 1998 Can oxidative DNA damage be used as a biomarker of cancer risk in humans? Problems, resolutions and preliminary results from nutritional supplementation studies. Free Radical Research 29 469-486. (https://doi.org/10.1080/10715769800300531)

Hammadeh ME, Hamad MF, Montenarh M \& FischerHammadeh C 2010 Protamine contents and P1/P2 ratio in human spermatozoa from smokers and non-smokers. Human Reproduction $\mathbf{2 5}$ 2708-2720. (https://doi.org/10.1093/humrep/deq226)

Harlev A, Agarwal A, Gunes So, Shetty A \& Du Plessis SS 2015 Smoking and male infertility: an evidence-based review. World Journal of Men's Health 33 143-160. (https://doi.org/10.5534/ wjmh.2015.33.3.143)

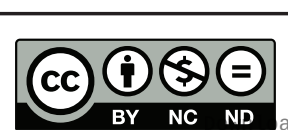

This work is licensed under a Creative Commons Attribution-NonCommercial-NoDerivatives 4.0 International License. International License. 
Hartmann A \& Speit G 1997 The contribution of cytotoxicity to DNAeffects in the single cell gel test (comet assay). Toxicology Letters 90 183-188. (https://doi.org/10.1016/s0378-4274(96)03847-7)

Hosen MB, Islam MR, Begum F, Kabir Y \& Howlader MZ 2015 Oxidative stress induced sperm DNA damage, a possible reason for male infertility. Iranian Journal of Reproductive Medicine 13 525-532.

Huang C, Cao X, Pang D, Li C, Luo Q, Zou Y, Feng B, Li L, Cheng A \& Chen Z 2018 Is male infertility associated with increased oxidative stress in seminal plasma? A-meta analysis. Oncotarget 9 24494-24513. (https://doi.org/10.18632/ oncotarget.25075)

Hughes SF, Haney AF \& Hughes Jr CL 1990 Use of human cumulus granulosa cells for in vitro screening of reproductive toxicants. Reproductive Toxicology 4 11-15. (https://doi.org/10.1016/08906238(90)90073-5)

Jarvis MJ, Tunstall-Pedoe H, Feyerabend C, Vesey C \& Saloojee Y 1987 Comparison of tests used to distinguish smokers from nonsmokers. American Journal of Public Health 77 1435-1438. (https://doi.org/10.2105/ajph.77.11.1435)

Jeulin C, Soufir JC, Weber P, Laval-Martin D \& Calvayrac R 1989 Catalase activity in human spermatozoa and seminal plasma. Gamete Research 24 185-196. (https://doi.org/10.1002/ mrd.1120240206)

Jirge PR 2016 Poor ovarian reserve. Journal of Human Reproductive Sciences 9 63-69. (https://doi.org/10.4103/0974-1208.183514)

Josarayi GA, Mohammad-Hasani A, Aftabi Y, Moudi E \& Hosseinzadeh Colagar A 2017 The AhRR-c.565C>G transversion may increase total antioxidant capacity levels of the seminal plasma in infertile men. Environmental Science and Pollution Research International 24 17428-17435. (https://doi.org/10.1007/s11356-0179356-z)

Jozwik M, Wolczynski S,Jozwik M\& Szamatowicz M 1999 Oxidative stress markers in preovulatory follicular fluid in humans. Molecular Human Reproduction 5 409-413. (https://doi.org/10.1093/ molehr/5.5.409)

Kala M, Shaikh MV \& Nivsarkar M 2017 Equilibrium between anti-oxidants and reactive oxygen species: a requisite for oocyte development and maturation. Reproductive Medicine and Biology 16 28-35. (https://doi.org/10.1002/rmb2.12013)

Kalemba-Drozdz M 2015 The interaction between air pollution and diet does not influence the DNA damage in lymphocytes of pregnant women. Environmental Research 136 295-299. (https://doi. org/10.1016/j.envres.2014.10.020)

Kazemi A, Ramezanzadeh F, Nasr-Esfahani MH, Saboor Yaraghi AA \& Ahmadi M 2013 Does dietary fat intake influence oocyte competence and embryo quality by inducing oxidative stress in follicular fluid? Iranian Journal of Reproductive Medicine $\mathbf{1 1}$ 1005-1012.

Kazemi A, Ramezanzadeh F, Nasr Esfahani MH, SaboorYaraghi AA, Nejat SN \& Rahimi-Foroshani A 2014 Relationship between energy expenditure related factors and oxidative stress in follicular fluid. International Journal of Fertility and Sterility 8 175-182.

Kazemi A, Ramezanzadeh F\& Nasr-Esfahani MH 2015 The relations between dietary antioxidant vitamins intake and oxidative stress in follicular fluid and ART outcomes. Iranian Journal of Reproductive Medicine 13 533-540.

Khan SN, Shaeib F, Najafi T, Kavdia M, Gonik B, Saed GM, Goud PT \& Abu-Soud HM 2015 Diffused intra-oocyte hydrogen peroxide activates myeloperoxidase and deteriorates oocyte quality. PLoS ONE 10 e0132388. (https://doi.org/10.1371/journal. pone.0132388

Khosravi F, Valojerdi MR, Amanlou M, Karimian L \& Abolhassani F 2014 Relationship of seminal reactive nitrogen and oxygen species and total antioxidant capacity with sperm DNA fragmentation in infertile couples with normal and abnormal sperm parameters. Andrologia 46 17-23. (https://doi.org/10.1111/ and.12034)

Khosrowbeygi A \& Zarghami N 2007 Levels of oxidative stress biomarkers in seminal plasma and their relationship with seminal parameters. BMC Clinical Pathology 7 6-6. (https://doi. org/10.1186/1472-6890-7-6)

Kullisaar T, Turk S, Kilk K, Ausmees K, Punab M \& Mändar R 2013 Increased levels of hydrogen peroxide and nitric oxide in male partners of infertile couples. Andrology 1 850-858. (https://doi. org/10.1111/j.2047-2927.2013.00123.x)

Kumar S, Murarka S, Mishra VV \& Gautam AK 2014 Environmental and lifestyle factors in deterioration of male reproductive health. Indian Journal of Medical Research 140 (Supplement) S29-S35.

Kumar S, Mishra V, Thaker R, Gor M, Perumal S, Joshi P, Sheth H, Shaikh I, Gautam AK \& Verma Y 2018 Role of environmental factors \& oxidative stress with respect to in vitro fertilization outcome. Indian Journal of Medical Research 148 S125-S133. (https://doi.org/10.4103/ijmr.IJMR_1864_17)

Kumaravel TS, Vilhar B, Faux SP \& Jha AN 2009 Comet assay measurements: a perspective. Cell Biology and Toxicology 25 53-64. (https://doi.org/10.1007/s10565-007-9043-9)

Kuo HW, Yang JS \& Chiu MC 2002 Determination of urinary and salivary cotinine using gas and liquid chromatography and enzymelinked immunosorbent assay. Journal of Chromatography: B, Analytical Technologies in the Biomedical and Life Sciences 768 297-303. (https:// doi.org/10.1016/s1570-0232(01)00613-4)

Lavery MR, Acharya P, Sivo SA \& Xu L 2019 Number of predictors and multicollinearity: what are their effects on error and bias in regression? Communications in Statistics: Simulation and Computation 48 27-38. (https://doi.org/10.1080/03610918.2017.1371750)

Layali I, Tahmasbpour E, Joulaei M, Jorsaraei SGA \& Farzanegi P 2015 Total antioxidant capacity and lipid peroxidation in semen of patient with hyperviscosity. Cell Journal 16 554-559. (https://doi.org/10.22074/cellj.2015.500)

Lee RF \& Steinert S 2003 Use of the single cell gel electrophoresis/ comet assay for detecting DNA damage in aquatic (marine and freshwater) animals. Mutation Research 544 43-64. (https://doi. org/10.1016/s1383-5742(03)00017-6)

Lee SF \& Pervaiz S 2011 Assessment of oxidative stress-induced DNA damage by immunoflourescent analysis of 8-oxodG. Methods in Cell Biology 103 99-113. (https://doi.org/10.1016/B978-0-12-3854933.00005-X)

Lee E, Oh E, Lee J, Sul D \& Lee J 2004 Use of the tail moment of the lymphocytes to evaluate DNA damage in human biomonitoring studies. Toxicological Sciences 81 121-132. (https://doi.org/10.1093/ toxsci/kfh184)

Lewis SE, John Aitken R, Conner SJ, Iuliis GD, Evenson DP, Henkel R, Giwercman A \& Gharagozloo P 2013 The impact of sperm DNA damage in assisted conception and beyond: recent advances in diagnosis and treatment. Reproductive Biomedicine Online 27 325-337. (https://doi.org/10.1016/j.rbmo.2013.06.014)

Lindley EM, Jacobson JD, Corselli J, King A \& Chan PJ 2001 Cryopreservation of human cumulus cells for co-cultures and assessment of DNA damage after thawing using the comet assay. Journal of Assisted Reproduction and Genetics 18 534-538. (https://doi. org/10.1023/a:1011991806423)

Linschooten JO, Laubenthal J, Cemeli E, Baumgartner A, Anderson D, Sipinen VE, Brunborg G, Haenen GR, Fthenou E, Briede JJ, et al. 2011 Incomplete protection of genetic integrity of mature spermatozoa against oxidative stress. Reproductive Toxicology 32 106-111. (https://doi.org/10.1016/j. reprotox.2011.05.004)

Liu Y, Yu Z, Zhao S, Cheng L, Man Y, Gao X \& Zhao H 2021 Oxidative stress markers in the follicular fluid of patients with polycystic ovary syndrome correlate with a decrease in embryo 
quality. Journal of Assisted Reproduction and Genetics 38 471-477. (https://doi.org/10.1007/s10815-020-02014-y)

Mancini A, Festa R, Di Donna V, Leone E, Littarru GP, Silvestrini A, Meucci E \& Pontecorvi A 2010 Hormones and antioxidant systems: role of pituitary and pituitary-dependent axes. Journal of Endocrinological Investigation 33 422-433. (https://doi. org/10.1007/BF03346615)

Mancini A, Di Segni C, Raimondo S, Olivieri G, Silvestrini A, Meucci E \& Curro D 2016 Thyroid hormones, oxidative stress, and inflammation. Mediators of Inflammation 2016 6757154. (https://doi. org/10.1155/2016/6757154)

Marnett LJ 1999 Lipid peroxidation-DNA damage by malondialdehyde. Mutation Research 424 83-95. (https://doi.org/10.1016/s00275107(99)00010-x)

Mecocci P, Polidori MC, Ingegni T, Cherubini A, Chionne F, Cecchetti R \& Senin U 1998 Oxidative damage to DNA in lymphocytes from AD patients. Neurology 51 1014-1017. (https://doi. org/10.1212/wnl.51.4.1014)

Micillo A, Vassallo MR, Cordeschi G, D'Andrea S, Necozione S, Francavilla F, Francavilla S \& Barbonetti A 2016 Semen leukocytes and oxidative-dependent DNA damage of spermatozoa in male partners of subfertile couples with no symptoms of genital tract infection. Andrology 4 808-815. (https://doi.org/10.1111/andr.12188)

Mintziori G, Kita M, Duntas L \& Goulis DG 2016 Consequences of hyperthyroidism in male and female fertility: pathophysiology and current management. Journal of Endocrinological Investigation 39 849-853. (https://doi.org/10.1007/s40618-016-0452-6)

Moller P, Danielsen PH, Karottki DG, Jantzen K, Roursgaard M, Klingberg H, Jensen DM, Christophersen DV, Hemmingsen JG, Cao Y, et al. 2014 Oxidative stress and inflammation generated DNA damage by exposure to air pollution particles. Mutation Research: Reviews in Mutation Research 762 133-166. (https://doi.org/10.1016/j.mrrev.2014.09.001)

Nakamura H, Kimura T, Nakajima A, Shimoya $K$, Takemura $M$, Hashimoto K, Isaka S, Azuma C, Koyama M \& Murata Y 2002 Detection of oxidative stress in seminal plasma and fractionated sperm from subfertile male patients. European Journal of Obstetrics, Gynecology, and Reproductive Biology 105 155-160. (https:// doi.org/10.1016/s0301-2115(02)00194-x)

Nicopoullos J, Vicens-Morton A, Lewis SEM, Lee K, Larsen P, Ramsay J, Yap T \& Minhas S 2019 Novel use of COMET parameters of sperm DNA damage may increase its utility to diagnose male infertility and predict live births following both IVF and ICSI. Human Reproduction 34 1915-1923. (https://doi.org/10.1093/ humrep/dez151)

Nunez-Calonge R, Cortes S, Gutierrez Gonzalez LM, Kireev R, Vara E, Ortega L, Caballero P, Rancan L \& Tresguerres J 2016 Oxidative stress in follicular fluid of young women with low response compared with fertile oocyte donors. Reproductive Biomedicine Online 32 446-456. (https://doi.org/10.1016/j. rbmo.2015.12.010)

O'Brien RM 2007 A caution regarding rules of thumb for variance inflation factors. Quality and Quantity 41 673-690. (https://doi. org/10.1007/s11135-006-9018-6)

Obuobie K \& Jones MK 2003 Hyperthyroidism with low thyroid hormone. Journal of the Royal Society of Medicine 96 185-186. (https:// doi.org/10.1258/jrsm.96.4.185)

Oremosu AA \& Akang EN 2015 Impact of alcohol on male reproductive hormones, oxidative stress and semen parameters in Sprague-Dawley rats. Middle East Fertility Society Journal 20 114-118. (https://doi.org/10.1016/j.mefs.2014.07.001)

Oyawoye O, Abdel Gadir A, Garner A, Constantinovici N, Perrett C \& Hardiman P 2003 Antioxidants and reactive oxygen species in follicular fluid of women undergoing IVF: relationship to outcome. Human Reproduction 18 2270-2274. (https://doi. org/10.1093/humrep/deg450)
Ozkaya MO \& Naziroglu M 2010 Multivitamin and mineral supplementation modulates oxidative stress and antioxidant vitamin levels in serum and follicular fluid of women undergoing in vitro fertilization. Fertility and Sterility 94 2465-2466. (https://doi. org/10.1016/j.fertnstert.2010.01.066)

Park JW \& Floyd RA 1992 Lipid peroxidation products mediate the formation of 8-hydroxydeoxyguanosine in DNA. Free Radical Biology and Medicine 12 245-250. (https://doi.org/10.1016/08915849(92)90111-s)

Pasqualotto FF, Sharma RK, Nelson DR, Thomas AJ \& Agarwal A 2000 Relationship between oxidative stress, semen characteristics, and clinical diagnosis in men undergoing infertility investigation. Fertility and Sterility 73 459-464. (https://doi. org/10.1016/s0015-0282(99)00567-1)

Pasqualotto EB, Agarwal A, Sharma RK, Izzo VM, Pinotti JA, Joshi NJ \& Rose BI 2004 Effect of oxidative stress in follicular fluid on the outcome of assisted reproductive procedures. Fertility and Sterility 81 973-976. (https://doi.org/10.1016/j. fertnstert.2003.11.021)

Pasqualotto FF, Umezu FM, Salvador M, Borges Jr E, Sobreiro BP \& Pasqualotto EB 2008 Effect of cigarette smoking on antioxidant levels and presence of leukocytospermia in infertile men: a prospective study. Fertility and Sterility 90 278-283. (https:// doi.org/10.1016/j.fertnstert.2008.02.123)

Pasqualotto EB, Lara LV, Salvador M, Sobreiro BP, Borges E \& Pasqualotto FF 2009 The role of enzymatic antioxidants detected in the follicular fluid and semen of infertile couples undergoing assisted reproduction. Human Fertility 12 166-171. (https://doi. org/10.1080/14647270903207941)

Paszkowski T 1998 Concentration gradient of cotinine between blood serum and preovulatory follicular fluid. Ginekologia Polska 69 1131-1136.

Peñarrubia J, Fábregues F, Creus M, Manau D, Casamitjana R, Guimerá M, Carmona F, Vanrell JA \& Balasch J 2003 LH serum levels during ovarian stimulation as predictors of ovarian response and assisted reproduction outcome in down-regulated women stimulated with recombinant FSH. Human Reproduction 18 2689-2697. (https://doi.org/10.1093/humrep/deg506)

Pilger A \& Rüdiger HW 2006 8-Hydroxy-2'-deoxyguanosine as a marker of oxidative DNA damage related to occupational and environmental exposures. International Archives of Occupational and Environmental Health 80 1-15. (https://doi.org/10.1007/s00420-0060106-7)

Raghunath A, Sundarraj K, Nagarajan R, Arfuso F, Bian J, Kumar AP, Sethi G \& Perumal E 2018 Antioxidant response elements: discovery, classes, regulation and potential applications. Redox Biology 17 297-314. (https://doi.org/10.1016/j. redox.2018.05.002)

Rahal A, Kumar A, Singh V, Yadav B, Tiwari R, Chakraborty S \& Dhama K 2014 Oxidative stress, prooxidants, and antioxidants: the interplay. BioMed Research International 2014 761264. (https:// doi.org/10.1155/2014/761264)

Rakhit M, Gokul SR, Agarwal A \& Du Plessis SS 2013 Antioxidant strategies to overcome OS in IVF-embryo transfer. In Studies on Women's Health. Eds A Agarwal, N Aziz \& B Rizk. Totowa, NJ: Humana Press.

Raman RS, Chan PJ, Corselli JU, Patton WC, Jacobson JD, Chan SR \& King A 2001 Comet assay of cumulus cell DNA status and the relationship to oocyte fertilization via intracytoplasmic sperm injection. Human Reproduction 16 831-835. (https://doi. org/10.1093/humrep/16.5.831)

Ramzan MH, Ramzan M, Khan MM, Ramzan F, Wahab F, Khan MA, Jillani M \& Shah M 2015 Human semen quality and sperm DNA damage assessed by comet assay in clinical groups. Turkish Journal of Medical Sciences 45 729-737. (https://doi. org/10.3906/sag-1407-50) 
Revelli A, Canosa S, Bergandi L, Skorokhod OA, Biasoni V, Carosso A, Bertagna A, Maule M, Aldieri E, D'Eufemia MD, et al. 2017 Oocyte polarized light microscopy assay of specific follicular fluid metabolites, and gene expression in cumulus cells as different approaches to predict fertilization efficiency after ICSI. Reproductive Biology and Endocrinology 1547. (https://doi.org/10.1186/s12958-017-0265-2)

Rosen EM, Mínguez-Alarcón L, Meeker JD, Williams PL, Milne GL, Hauser R, Ferguson KK \& EARTH Study Team 2019 Urinary oxidative stress biomarker levels and reproductive outcomes among couples undergoing fertility treatments. Human Reproduction 34 2399-2409. (https://doi.org/10.1093/humrep/ dez228)

Roychoudhury S, Sharma R, Sikka S \& Agarwal A 2016 Diagnostic application of total antioxidant capacity in seminal plasma to assess oxidative stress in male factor infertility. Journal of Assisted Reproduction and Genetics 33 627-635. (https://doi. org/10.1007/s10815-016-0677-5)

Ruder EH, Hartman TJ, Blumberg J \& Goldman MB 2008 Oxidative stress and antioxidants: exposure and impact on female fertility. Human Reproduction Update 14 345-357. (https://doi. org/10.1093/humupd/dmn011)

Sabeti P, Pourmasumi S, Rahiminia T, Akyash F \& Talebi AR 2016 Etiologies of sperm oxidative stress. International Journal of Reproductive Biomedicine 14 231-240. (https://doi.org/10.29252/ ijrm.14.4.231)

Sakamoto Y, Ishikawa T, Kondo Y, Yamaguchi K \& Fujisawa M 2008 The assessment of oxidative stress in infertile patients with varicocele. BJU International 101 1547-1552. (https://doi. org/10.1111/j.1464-410X.2008.07517.x)

Saleh RA, Agarwal A, Sharma RK, Nelson DR \& Thomas Jr AJ 2002 Effect of cigarette smoking on levels of seminal oxidative stress in infertile men: a prospective study. Fertility and Sterility 78 491-499. (https://doi.org/10.1016/s0015-0282(02)03294-6)

Sanocka D \& Kurpisz M 2004 Reactive oxygen species and sperm cells. Reproductive Biology and Endocrinology 2 12-12. (https://doi. org/10.1186/1477-7827-2-12)

Schulte RT, Ohl DA, Sigman M \& Smith GD 2010 Sperm DNA damage in male infertility: etiologies, assays, and outcomes. Journal of Assisted Reproduction and Genetics 27 3-12. (https://doi. org/10.1007/s10815-009-9359-x)

Seino T, Saito H, Kaneko T, Takahashi T, Kawachiya S \& Kurachi H 2002 Eight-hydroxy-2'-deoxyguanosine in granulosa cells is correlated with the quality of oocytes and embryos in an in vitro fertilization-embryo transfer program. Fertility and Sterility $\mathbf{7 7}$ 1184-1190. (https://doi.org/10.1016/s0015-0282(02)03103-5)

Sharma RK \& Agarwal A 1996 Role of reactive oxygen species in male infertility. Urology 48 835-850. (https://doi.org/10.1016/s00904295(96)00313-5)

Sharma P, Jha AB, Dubey RS \& Pessarakli M 2012 Reactive oxygen species, oxidative damage, and antioxidative defense mechanism in plants under stressful conditions. Journal of Botany 2012 1-26. (https://doi.org/10.1155/2012/217037)

Sharma R, Roychoudhury S, Singh N \& Sarda Y 2017 Methods to measure reactive oxygen species (ROS) and total antioxidant capacity (TAC) in the reproductive system. In Oxidative Stress in Human Reproduction: Shedding Light on a Complicated Phenomenon. Eds A Agarwal, R Sharma, S Gupta, A Harlev, G Ahmad, SS Du Plessis, SC Esteves, SM Wang \& D Durairajanayagam. Cham: Springer International Publishing.

Shen H \& Ong C 2000 Detection of oxidative DNA damage in human sperm and its association with sperm function and male infertility. Free Radical Biology and Medicine 28 529-536. (https://doi. org/10.1016/s0891-5849(99)00234-8)

Shi X, Chan DYL, Zhao MP, Chan CPS, Huang J \& Li TC 2019 Comparison of DNA fragmentation levels in spermatozoa with different sex chromosome complements. Reproductive Biomedicine Online 38 56-65. (https://doi.org/10.1016/j.rbmo.2018.10.005)

Simon L \& Carrell DT 2013 Sperm DNA damage measured by comet assay. Methods in Molecular Biology 927 137-146. (https://doi. org/10.1007/978-1-62703-038-0_13)

Simon L, Emery BR \& Carrell DT 2017 Review: diagnosis and impact of sperm DNA alterations in assisted reproduction. Best Practice and Research: Clinical Obstetrics and Gynaecology 44 38-56. (https://doi. org/10.1016/j.bpobgyn.2017.07.003)

Singh NP, Mccoy MT, Tice RR \& Schneider EL 1988 A simple technique for quantitation of low levels of DNA damage in individual cells. Experimental Cell Research 175 184-191. (https://doi. org/10.1016/0014-4827(88)90265-0)

Singh NP, Muller CH \& Berger RE 2003 Effects of age on DNA double-strand breaks and apoptosis in human sperm. Fertility and Sterility 80 1420-1430. (https://doi.org/10.1016/j. fertnstert.2003.04.002)

Singh AK, Chattopadhyay R, Chakravarty B \& Chaudhury K 2013 Markers of oxidative stress in follicular fluid of women with endometriosis and tubal infertility undergoing IVF. Reproductive Toxicology 42 116-124. (https://doi.org/10.1016/j. reprotox.2013.08.005)

Sinko I, Morocz M, Zadori J, Kokavszky K \& Rasko I 2005 Effect of cigarette smoking on DNA damage of human cumulus cells analyzed by comet assay. Reproductive Toxicology 20 65-71. (https:// doi.org/10.1016/j.reprotox.2004.12.007)

Tamura H, Takasaki A, Miwa I, Taniguchi K, Maekawa R, Asada H, Taketani T, Matsuoka A, Yamagata Y, Shimamura K, et al. 2008 Oxidative stress impairs oocyte quality and melatonin protects oocytes from free radical damage and improves fertilization rate. Journal of Pineal Research 44 280-287. (https://doi.org/10.1111/j.1600-079X.2007.00524.x)

Tamura H, Takasaki A, Nakamura Y, Numa F \& Sugino $\mathbf{N}$ 2014 A pilot study to search possible mechanisms of ultralong gonadotropin-releasing hormone agonist therapy in IVF-ET patients with endometriosis. Journal of Ovarian Research 7 100. (https://doi. org/10.1186/s13048-014-0100-8)

Tang LX, Yuan DJ, Wang QL, Jiang F, Guo J, Tang YG, Zheng LX \& Kang JX 2016 Association of decreased spermatozoa omega-3 fatty acid levels and increased oxidative DNA damage with varicocele in infertile men: a case control study. Reproduction, Fertility, and Development 28 648-654. (https://doi.org/10.1071/ RD14276)

Tarlatzis BC, Zepiridis L, Grimbizis G \& Bontis J 2003 Clinical management of low ovarian response to stimulation for IVF: a systematic review. Human Reproduction Update 9 61-76. (https://doi. org/10.1093/humupd/dmg007)

Tatemoto H, Sakurai N \& Muto N 2000 Protection of porcine oocytes against apoptotic cell death caused by oxidative stress during in vitro maturation: role of cumulus cells. Biology of Reproduction 63 805-810. (https://doi.org/10.1095/biolreprod63.3.805)

Tchou J \& Grollman AP 1993 Repair of DNA containing the oxidatively-damaged base, 8-oxoguanine. Mutation Research 299 277-287. (https://doi.org/10.1016/0165-1218(93)90104-1)

Terasaka T, Adakama ME, Li S, Kim T, Terasaka E, Li D \& Lawson MA 2017 Reactive oxygen species link Ggonadotropinreleasing hormone receptor signaling cascades in the gonadotrope. Frontiers in Endocrinology 8 286. (https://doi.org/10.3389/ fendo.2017.00286)

Terzioğlu F, Karahalil B, Yücel Ç \& Türk R 2016 The effect of cotinine concentrations in seminal plasma and follicular fluid on the pregnancy outcomes of couples undergoing assisted reproductive techniques. Turkish Journal of Medical Sciences 46 1495-1501. (https:// doi.org/10.3906/sag-1504-121)

Thaker R, Mishra V, Gor M, Agarwal R, Sheth H, Kapadia P \& Kumar S 2020 The role of stimulation protocol, number of oocytes

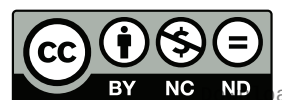

This work is licensed under a Creative Commons Attribution-NonCommercial-NoDerivatives 4.0 International License. ded from Bioscientifica.com at 04/26/2023 12:50:10AM 
retrieved with respect to follicular fluid oxidative stress and IVF outcome. Human Fertility 23 23-31. (https://doi.org/10.1080/146472 73.2018.1551630)

Tola EN, Koşar PA, Karatopuk DU, Sancer O \& Oral B 2019 Effect of DNA damage of cumulus oophorus cells and lymphocytes analyzed by alkaline comet assay on oocyte quality and intracytoplasmic sperm injection success among patients with polycystic ovary syndrome. Journal of Obstetrics and Gynaecology Research 45 609-618. (https://doi.org/10.1111/jog.13868)

Ulloa-Aguirre A \& Lira-Albarran S 2016 Clinical applications of gonadotropins in the male. Progress in Molecular Biology and Translational Science 143 121-174. (https://doi.org/10.1016/ bs.pmbts.2016.08.003)

Uppangala S, Fernandes G, Salian SR, Kumar P, Talevi R, Kalthur G \& Adiga SK 2020 Reduced ovarian response to controlled ovarian stimulation is associated with increased oxidative stress in the follicular environment. Reproductive Biology 20 402-407. (https://doi.org/10.1016/j.repbio.2020.04.005)

Vannuccini S, Clifton VL, Fraser IS, Taylor HS, Critchley H, Giudice LC \& Petraglia F 2016 Infertility and reproductive disorders: impact of hormonal and inflammatory mechanisms on pregnancy outcome. Human Reproduction Update 22 104-115. (https://doi.org/10.1093/humupd/dmv044)

Varnagy A, Koszegi T, Gyorgyi E, Szegedi S, Sulyok E \& Premusz V 2018 Levels of total antioxidant capacity and 8-hydroxy-2'-deoxyguanosine of serum and follicular fluid in women undergoing in vitro fertilization: focusing on endometriosis. Human Fertility 1-9.

Várnagy Á, Kőszegi T, Györgyi E, Szegedi S, Sulyok E, Prémusz V \& Bódis J 2020 Levels of total antioxidant capacity and 8-hydroxy2 '-deoxyguanosine of serum and follicular fluid in women undergoing in vitro fertilization: focusing on endometriosis. Human Fertility 23 200-208. (https://doi.org/10.1080/14647273.2018.1535 719)

Vatannejad A, Tavilani H, Sadeghi MR, Amanpour S, Shapourizadeh S \& Doosti M 2017 Evaluation of ROS-TAC score and DNA damage in fertile normozoospermic and infertile asthenozoospermic males. Urology Journal 14 2973-2978.
Venkatesh S, Shamsi MB, Dudeja S, Kumar R \& Dada R 2011 Reactive oxygen species measurement in neat and washed semen: comparative analysis and its significance in male infertility assessment. Archives of Gynecology and Obstetrics 283 121-126. (https://doi.org/10.1007/s00404-010-1645-4)

Villanueva I, Alva-Sánchez C \& Pacheco-Rosado J 2013 The role of thyroid hormones as inductors of oxidative stress and neurodegeneration. Oxidative Medicine and Cellular Longevity 2013 218145.

Vine MF, Hulka BS, Margolin BH, Truong YK, Hu PC, Schramm MM, Griffith JD, Mccann M \& Everson RB 1993 Cotinine concentrations in semen, urine, and blood of smokers and nonsmokers. American Journal of Public Health 83 1335-1338. (https://doi.org/10.2105/ajph.83.9.1335)

Wdowiak A \& Wdowiak A 2015 Comparing antioxidant enzyme levels in follicular fluid in ICSI-treated patients. Gynecologie, Obstetrique and Fertilite 43 515-521. (https://doi.org/10.1016/j.gyobfe.2015.06.004)

Zandieh Z, Vatannejad A, Doosti M, Zabihzadeh S, Haddadi M, Bajelan L, Rashidi B \& Amanpour S 2018 Comparing reactive oxygen species and DNA fragmentation in semen samples of unexplained infertile and healthy fertile men. Irish Journal of Medical Science 187 657-662. (https://doi.org/10.1007/s11845-017-1708-7)

Zenzes MT, Puy LA \& Bielecki R 1997 Immunodetection of cotinine protein in granulosa-lutein cells of women exposed to cigarette smoke. Fertility and Sterility 68 76-82. (https://doi.org/10.1016/s00150282(97)81479-3)

Zhuo L \& Kimata K 2001 Cumulus oophorus extracellular matrix: its construction and regulation. Cell Structure and Function 26 189-196. (https://doi.org/10.1247/csf.26.189)

Zubair M, Ahmad M \& Qureshi ZI 2017 Review on arsenic-induced toxicity in male reproductive system and its amelioration. Andrologia 49. (https://doi.org/10.1111/and.12791)

Received in final form 15 April 2021

Accepted 23 April 2021

Accepted Manuscript published online 23 April 2021 (c) 2021 The authors Published by Bioscientifica Ltd
This work is licensed under a Creative Commons Attribution-NonCommercial-NoDerivatives 4.0 International License. ded from Bioscientifica.com at 04/26/2023 12:50:10AM 